\title{
Tree Seed and Seedling Systems for Resilience and Productivity
}

Ten years of

forests, trees and agroforestry research in partnership for sustainable development 


\section{About the FTA Highlights series}

This publication is part of a series that highlights the main findings, results and achievements of the CGIAR Research Program on Forests, Trees and Agroforestry (FTA), from 2011 to 2021 (see full list of chapters on the last page).

FTA, the world's largest research for development partnership on forests, trees and agroforestry, started in 2011. FTA gathers partners that work across a range of projects and initiatives, organized around a set of operational priorities. Such research was funded by multiple sources: CGIAR funders through program-level funding, and funders of bilateral projects attached to the programme, undertaken by one or several of its partners. Overall this represented an effort of about 850 million USD over a decade.

The ambition of this series is, on each topic, to show the actual contributions of FTA to research and development challenges and solutions over a decade. It features the work undertaken as part of the FTA program, by the strategic partners of FTA (CIFOR-ICRAF, The Alliance of Bioversity and CIAT, CATIE, CIRAD, Tropenbos and INBAR) and/or with other international and national partners. Such work is presented indifferently in the text as work "from FTA" and/ or from the particular partner/organization that led it. Most of the references cited are from the FTA program.

This series was elaborated under the leadership of the FTA Director, overall guidance of an Editorial Committee constituted by the Management Team of FTA, support from the FTA Senior Technical Advisor, and oversight of the FTA Independent Steering Committee whose independent members acted as peer-reviewers of all the volumes in the series.

FTA HIGHLIGHTS OF A DECADE 2011-2021

Tree Seed and Seedling Systems for Resilience and Productivity

(C) 2021 The CGIAR Research Program on Forests, Trees and Agroforestry (FTA)

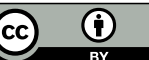

Content in this publication is licensed under a Creative Commons Attribution 4.0

International (CC BY 4.0), http://creativecommons.org/licenses/by/4.0/

DOI: $10.17528 /$ cifor/008212

Graudal L, Lillesø J-PB, Dawson IK, Abiyu A, Roshetko JM, Nyoka I, Tsobeng A, Kindt R, Pedercini F, Moestrup S, Jalonen R, Thomas E, McMullin S, Garsan S, Hendre P, Kettle C, Li Y and Jamnadass R. 2021. Tree Seed and Seedling Systems for Resilience and Productivity. FTA Highlights of a Decade 2011-2021 series. Highlight No. 2. Bogor, Indonesia: The CGIAR Research Program on Forests, Trees and Agroforestry (FTA).

CGIAR Research Program on Forests, Trees and Agroforestry

CIFOR Headquarters

Jalan CIFOR

Situ Gede, Sindang Barang

Bogor Barat 16115 Indonesia

$\mathrm{T}+62-251-8622-622$

E cgiarforestsandtrees@cgiar.org

foreststreesagroforestry.org

We would like to thank all funding partners who supported this research through their contributions to the CGIAR Fund. For a full list of the 'CGIAR Fund' funding partners please see: http://www.cgiar.org/ourfunders.

Any views expressed in this publication are those of the authors. They do not necessarily represent the views of The CGIAR Research Program on Forests, Trees and Agroforestry (FTA), the editors, the authors' institutions, the financial sponsors or the reviewers.

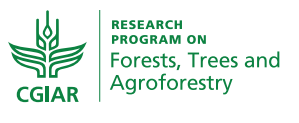




\section{Tree Seed and Seedling Systems for Resilience and Productivity}

Lead author: Lars Graudal

Gontributing authors: Jens-Peter B. Lillesø, Ian K. Dawson, Abrham Abiyu, James M. Roshetko, Isaac Nyoka, Alain Tsobeng, Roeland Kindt, Fabio Pedercini, Soren Moestrup, Riina Jalonen, Evert Thomas, Stepha McMullin, Sammy Carsan, Prasad Hendre, Christopher Kettle, Yanxia X. Li and Ramni Jamnadass

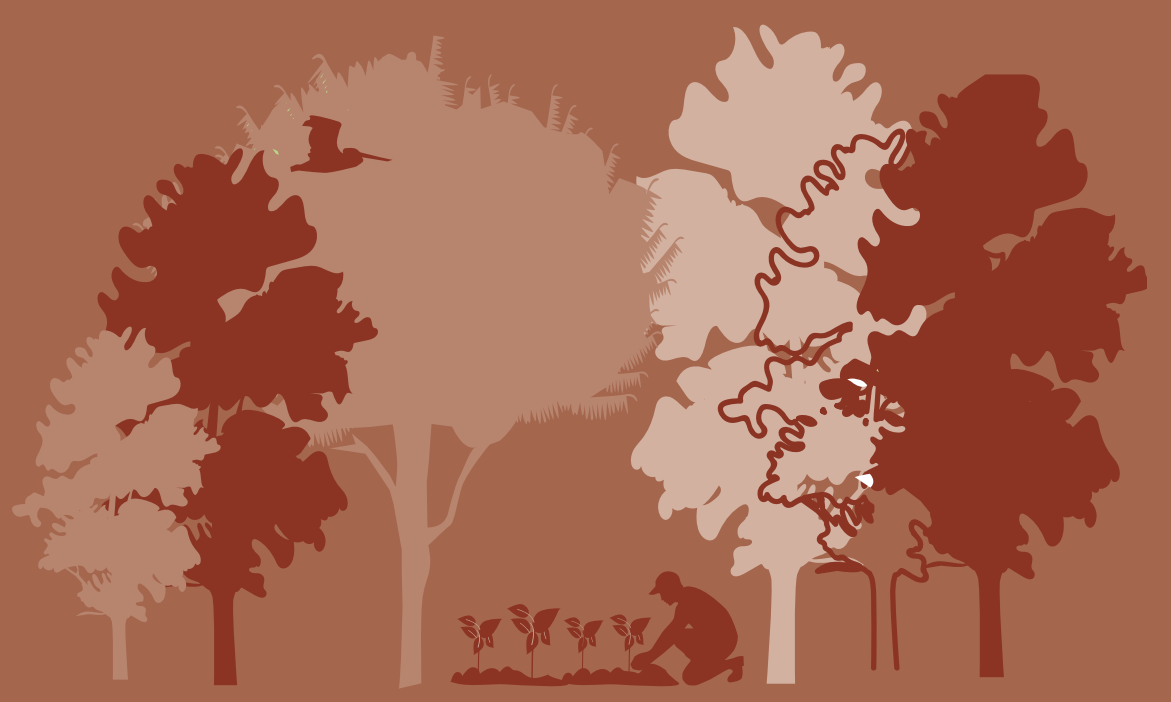




\section{Editorial and publication team}

Editorial Committee of the Highlights Series

Vincent Gitz (Chairperson of the Editorial Committee), Michael Allen Brady, René Boot, Marlène Elias, Ramni H. Jamnadass, Christopher Kettle, Yanxia Li, Christopher Martius, Alexandre Meybeck, Peter A. Minang, Fergus Sinclair, Plinio Sist and Eduardo Somarriba.

\section{Independent Steering Gommittee of FTA}

Anne-Marie Izac (Chairperson of the ISC), René Boot, Susan Braatz, Linda Collette, Vincent Gitz, Florencia Montagnini, Richard Stanislaus Muyungi, Robert Nasi and Stephan Weise.

\section{FTA Director}

Vincent Gitz

\section{FTA Highlights Support Team}

Technical and scientific editing: Alexandre Meybeck, FTA senior technical advisor Coordination of publication process, editing and layout: Fabio Ricci, FTA communications coordinator Coordination of the peer-review process: Monika Kiczkajlo, FTA program manager Language editing and referencing: Patricia Halladay, consultant

Layout and design: Dharmi Bradley, consultant

\section{Acknowledgements}

Our thanks to the CGIAR funding partners that made this work possible. Our thanks also to the many FTA scientists and research and development partners who have been involved.

We gratefully acknowledge Florencia Montagnini and Linda Collette for their constructive review and feedback on an earlier version of the manuscript. 


\section{Table of contents}

Executive summary..................................................... 4

1. Introduction................................................................. 6

2. Improving the availability of quality tree seed................ 12

3. Supporting better decision making in what to plant where and for what purpose............................................. 22

4. Future directions..................................................... 27

References......................................................................... 30

List of acronyms

AfPBA African Plant Breeding Academy

AFR100 African Forest Landscape Restoration Initiative

APBA African Plant Breeders Association

BSF Banco de semillas forestales (Forest Seed Bank)

BSO Breeding seedling orchard

D4R Diversity for Restoration tool

GRU Genetic Resources Unit

GTKP Global Tree Knowledge Platform

NOEL Nurseries of excellence

PATSPO Provision of Adequate Tree Seed Portfolios

RRC Rural resource centre

RTPP Resources for Tree Planting Platform

V4A Vegetationmap4Africa 


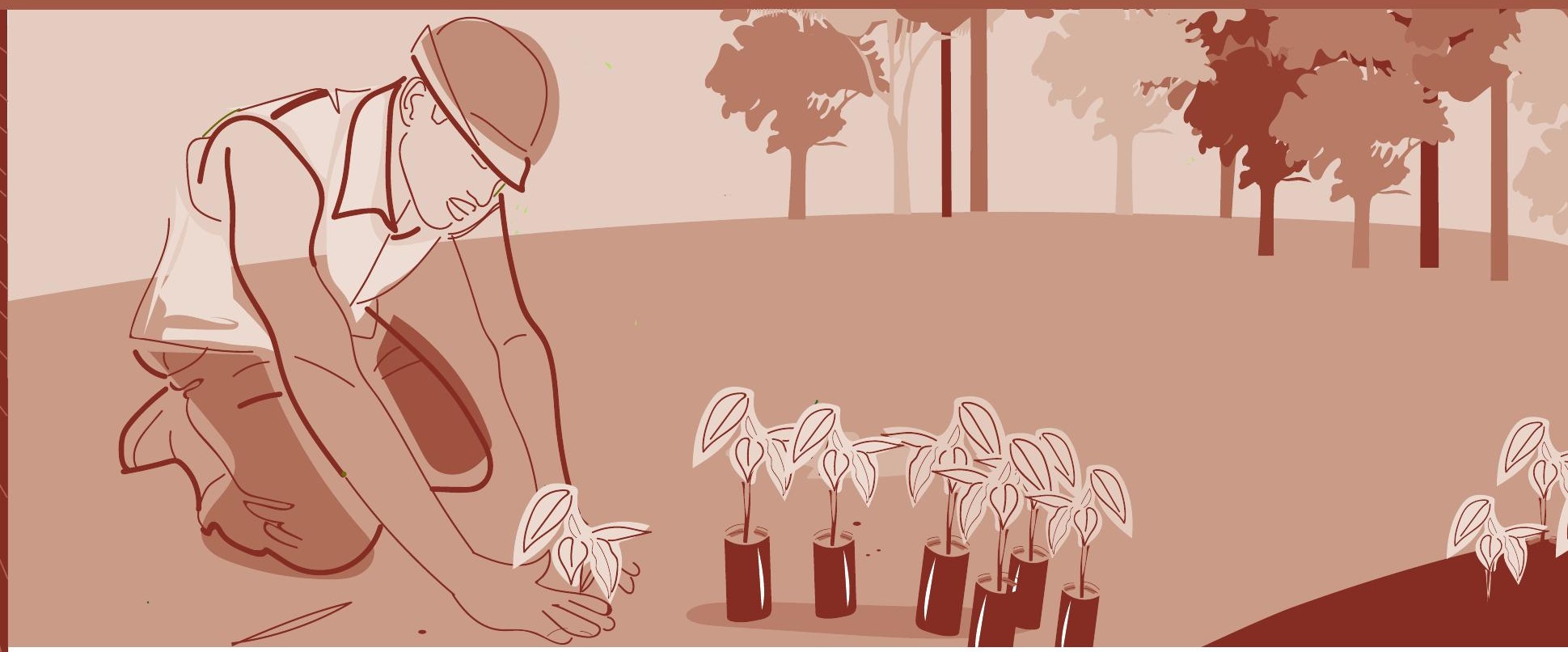

\section{Executive summary}

The work of the GGIAR Research Program on Forests, Trees and

Agroforestry (FTA) on tree seed systems - the authors' shorthand for the means through which growers obtain access to tree-planting materials, either seeds or seedlings - has sought to address significant constraints in the diversity and genetic quality of the tree seeds and seedlings that are being supplied. These concerns are exacerbated by an increase in demand for germplasm to meet huge global forest landscape restoration commitments and other tree-planting targets. Over the last decade, FTA has worked on twin concerns in this regard: first, how to make available quality tree-planting material; and second, how to ensure that tree seeds and seedlings are planted in the right places for the right purposes. It has addressed availability through building stakeholder partnerships and model tree seed systems; delivering improved "orphan" (under-researched) tree crops through supporting breeding and its impact; mainstreaming food trees through nurseries; conserving and making available diverse tree germplasm to support delivery and use; and developing policies to support the effective supply of tree seeds and seedlings. It has supported better decision making through building information platforms to support tree-planting choices and tree seed system operations; designing maps to guide tree seed and seedling distribution that is suited to current and predicted future climatic conditions; and releasing statistical packages to guide appropriate tree planting and assess the impacts of this planting in terms of benefits such as additional carbon sequestered and extra soil protected. This work is the foundation of local and global economic and environmental benefits of huge significance. It supports climate change mitigation and adaptation, restores landscapes and conserves biodiversity, and 


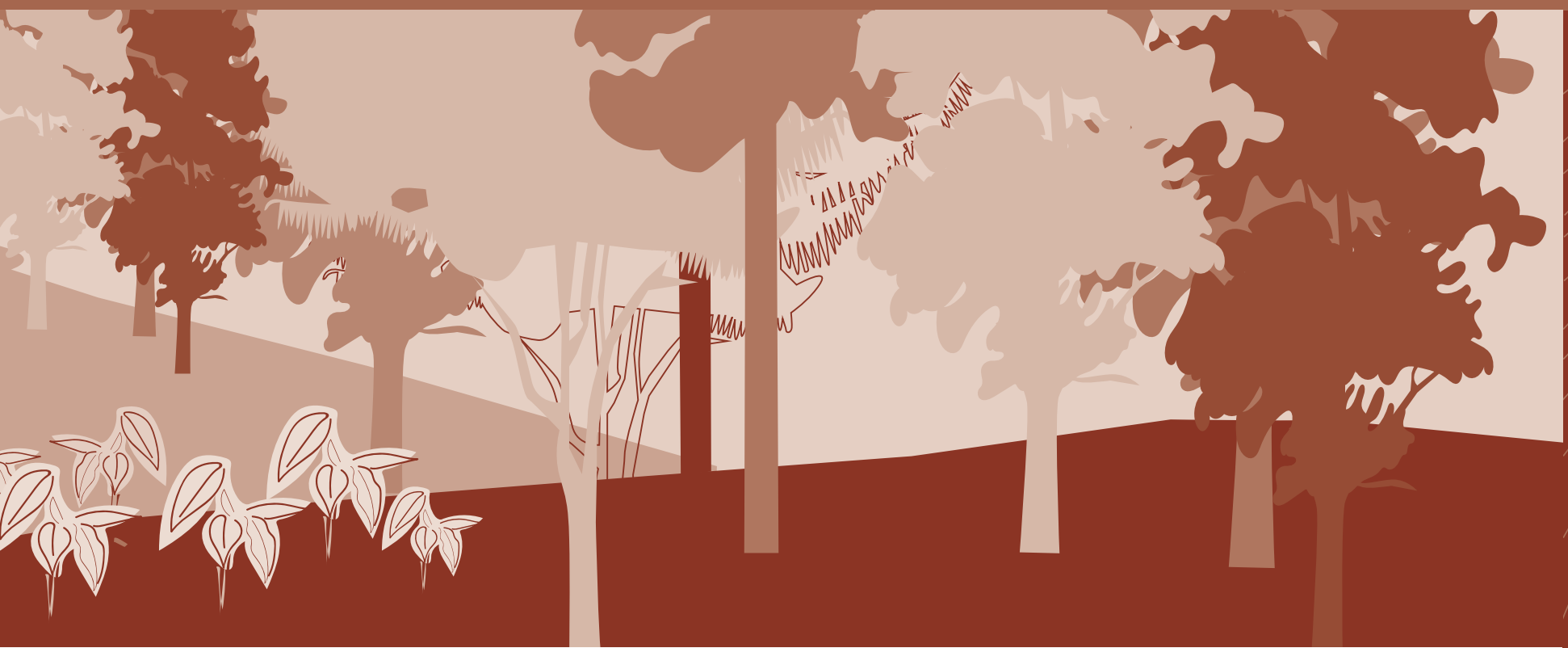

provides healthy foods and other products for local and global communities. This publication focuses on FTA's work in these areas. Future directions for work identified include a closer analysis of the relative importance of supplyside versus demand-side measures for mainstreaming improved tree genetic materials by growers; working with investors to improve tree seed quality at the project design stage of tree-planting programmes; and scaling up existing tree seed systems experience to burgeoning forest landscape restoration and broader tree planting initiatives. This scaling up will involve further engagement with major global initiatives such as the Bonn Challenge, the UN Decade on Ecosystem Restoration 2021-2030, and the Global Plan of Action on Forest Genetic Resources.

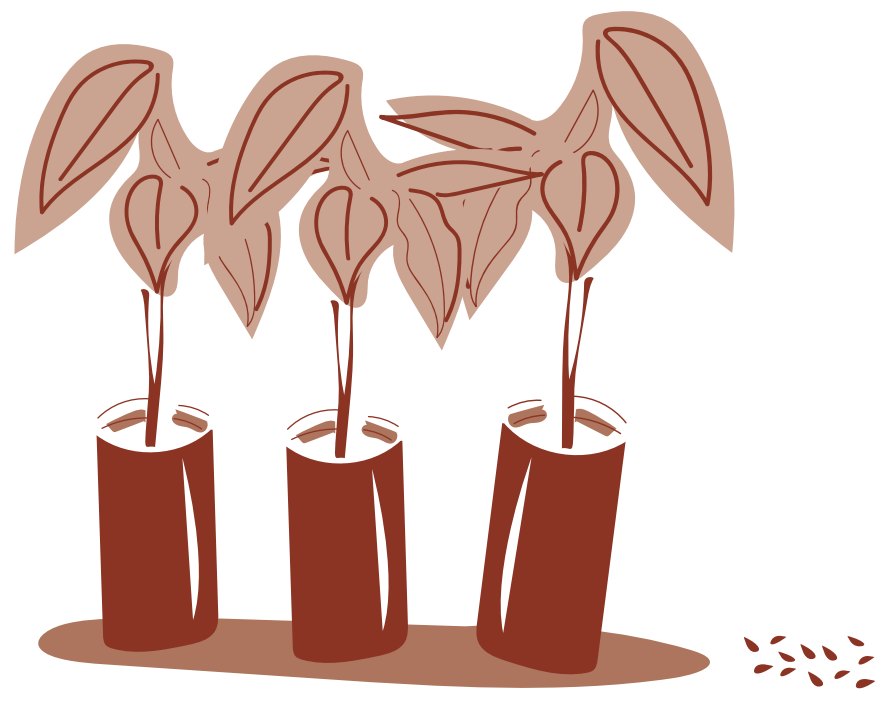




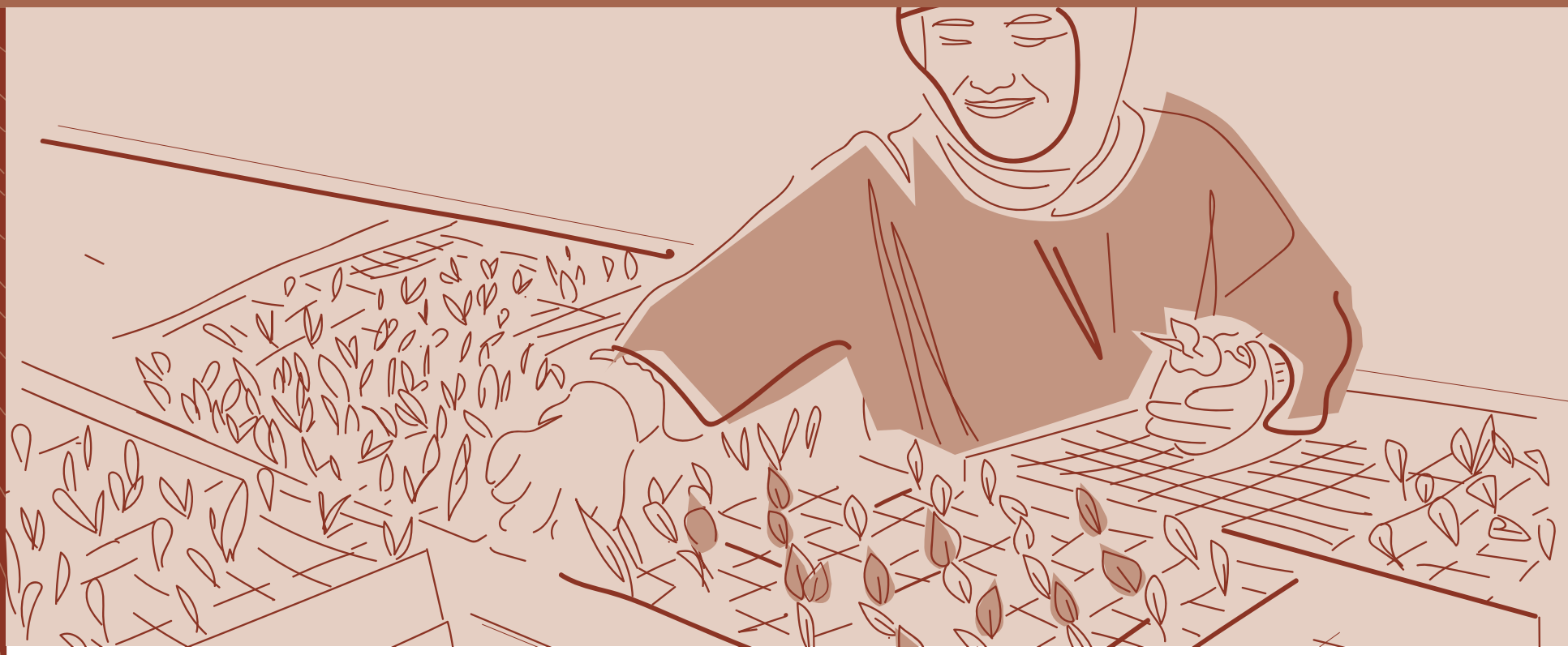

\section{Introduction}

Tree seed systems - as defined in Box 1 and the authors' shorthand for the sourcing of both tree seeds and seedlings for planting purposes - are the starting point from which farmers, foresters and others are able to grow trees. These systems have been a major topic of work by the CGIAR Research Program on Forests, Trees and Agroforestry (FTA) in the last decade because of the current constraints faced by growers in obtaining tree-planting material of good quality (Nyoka et al. 2015b). Even when quality tree seeds are available for planting, growers do not always know or fully consider what trees to plant, and where, so that they are effectively matched to planting environments and purposes (Cernansky 2018). It is common for inappropriate tree species or seeds or seedlings with unsuitable provenance (particular origin) to be planted, often with a few exotic species being used rather than a broader mix of more appropriate indigenous and exotic trees (Thomas et al. 2014; Jalonen et al. 2018; Roshetko et al. 2018). This lack of attention to what is planted, and the ecological havoc this may cause, is a topic discussed globally by societies who are rightly and increasingly questioning the effectiveness of current 'restoration' practices (e.g. see the criticisms in popular media such as Williams 2020 and Jones 2021, and the more scientific but still broadly accessible critical viewpoint of Fleischman et al. 2020). For more information about work on forest and landscape restoration conducted within FTA, see Highlight No. 4 in this series (Guariguata et al. 2021).

In the last decade, FTA scientists have brought these deficiencies in tree seed sourcing to the attention of forest landscape restoration practitioners and 
the wider tree planting community. A recent comment piece in the journal Science, for example, took up this topic after interviews with FTA researchers (Cernansky 2021). The article explains how the struggle to make headway in the African Union's Great Green Wall restoration initiative (GGW 2021) is in part due to problems in tree seed sourcing. FTA scientists quoted in the piece elaborated on the problems faced, and how, unfortunately, the costs of poor tree seed sourcing are borne mostly by the planters who establish and grow the trees, not the planners who design the interventions.

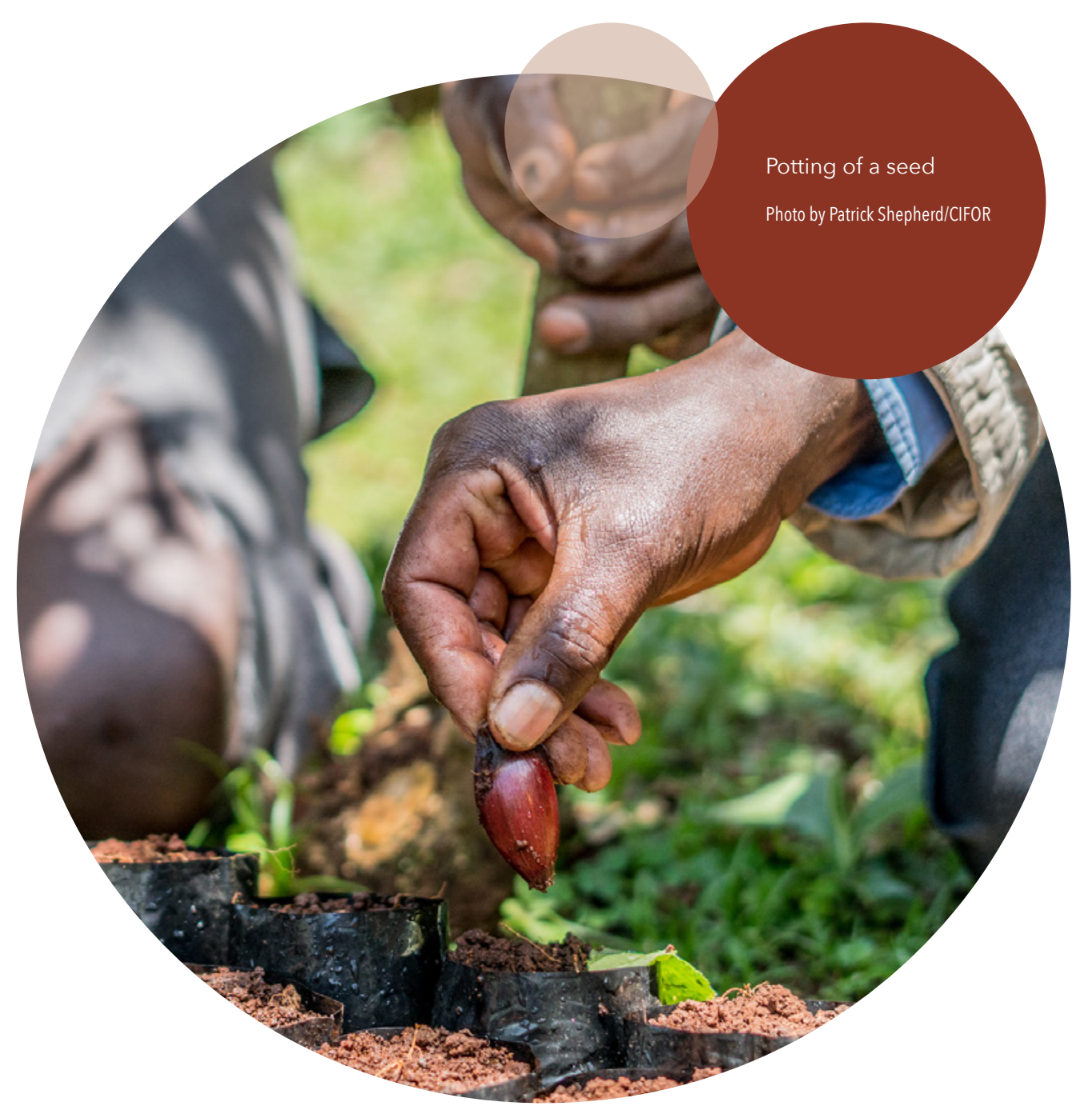


The problem of tree seed sourcing is becoming ever more acute due to the increased demand for seeds to meet now-massive global commitments to forest landscape restoration and other tree planting initiatives. Coincident with the beginning of the FTA program in 2011, for example, the Bonn Challenge (Bonn Challenge 2021) seeks to bring 350 million ha of degraded and deforested landscapes globally into restoration by 2030 , through a combination of facilitated natural regeneration and planting (often tree planting). The United Nations considers such restoration as a key challenge for the next 10 years, and has thus designated the decade of 2021 to 2030 as the UN Decade on Ecosystem Restoration (UN 2021); although this is obviously

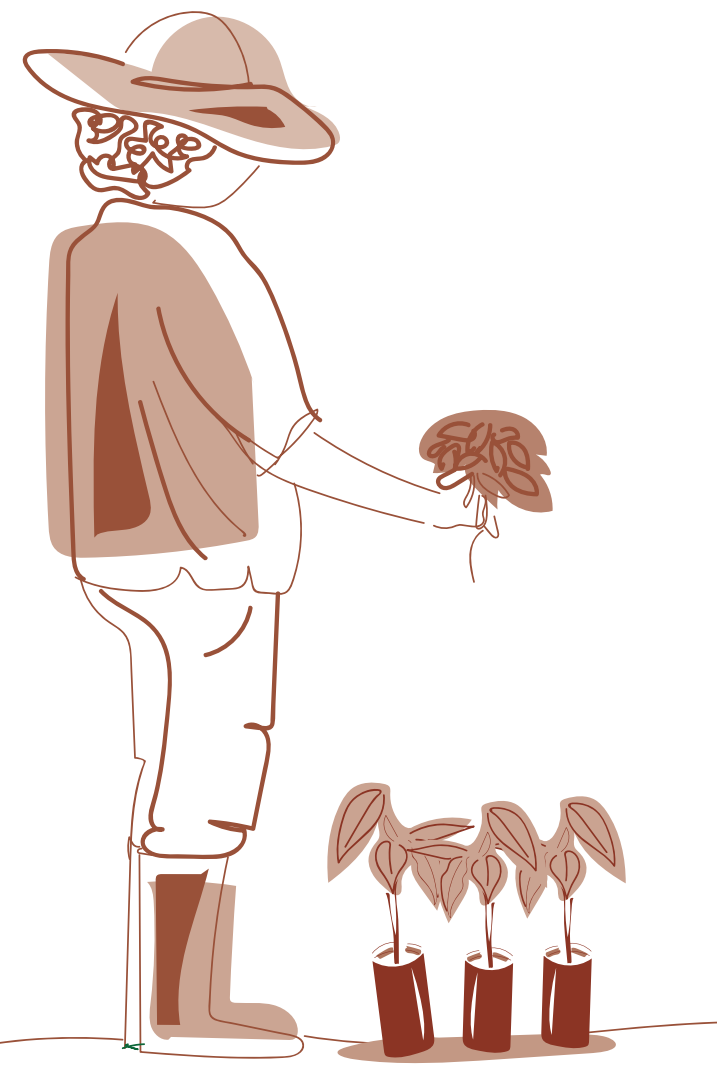
a welcome development, it also further illustrates how overstretched current tree seed systems are.

Responding to these restoration initiatives and the recent greater focus on accountability in how tree planting is done (Holl and Brancalion 2020; Di Sacco et al. 2021) provides new opportunities for bringing about the necessary improvements in tree seed sourcing practices. Over the last decade, FTA has positioned itself to take advantage of these opportunities for the benefit of growers' livelihoods and to provide more effective nature-based solutions to environmental problems, including climate change. FTA's work, as described in the current Highlight, seeks to address twin concerns in this regard: first, how to make available quality tree planting material through appropriate partnerships, supply models, linked conservation strategies, policies, and the like; and second, how to ensure that tree seeds and seedlings are planted in the right places for the right purposes through building and disseminating decisionsupport tools. Information on conservation strategies that support seed supply can be found in Highlight 3 in this series on conservation of tree biodiversity and sustainable forest management (Vinceti et al. 2021). 
The importance of addressing the above two concerns can hardly be overemphasized. It has been estimated that natural climate solutions, for example, could provide over one-third of the cost-effective climate mitigation needed between now and 2030 to stabilize planetary warming to below $2^{\circ} \mathrm{C}$ (Griscom et al. 2017), and at the same time provide benefits to economies, biodiversity and human health (Rosenstock et al. 2019). These solutions would involve reforestation of up to 0.7 billion ha of land, with better tree plantations and more trees in agricultural lands on an additional similar area of land (Griscom et al. 2017), together representing 10\% or more of the global terrestrial surface. Provided these twin concerns are met, along with the implementation of other principles of good restoration practice (Di Sacco et al. 2021), the ecological havoc that may be caused by inappropriate 'restoration' can be avoided and genuine restoration can be achieved (Girardin et al. 2021). This would better support the goals of the Bonn Challenge and the UN Decade on Ecosystem Restoration, and provide support for other global and regional initiatives.

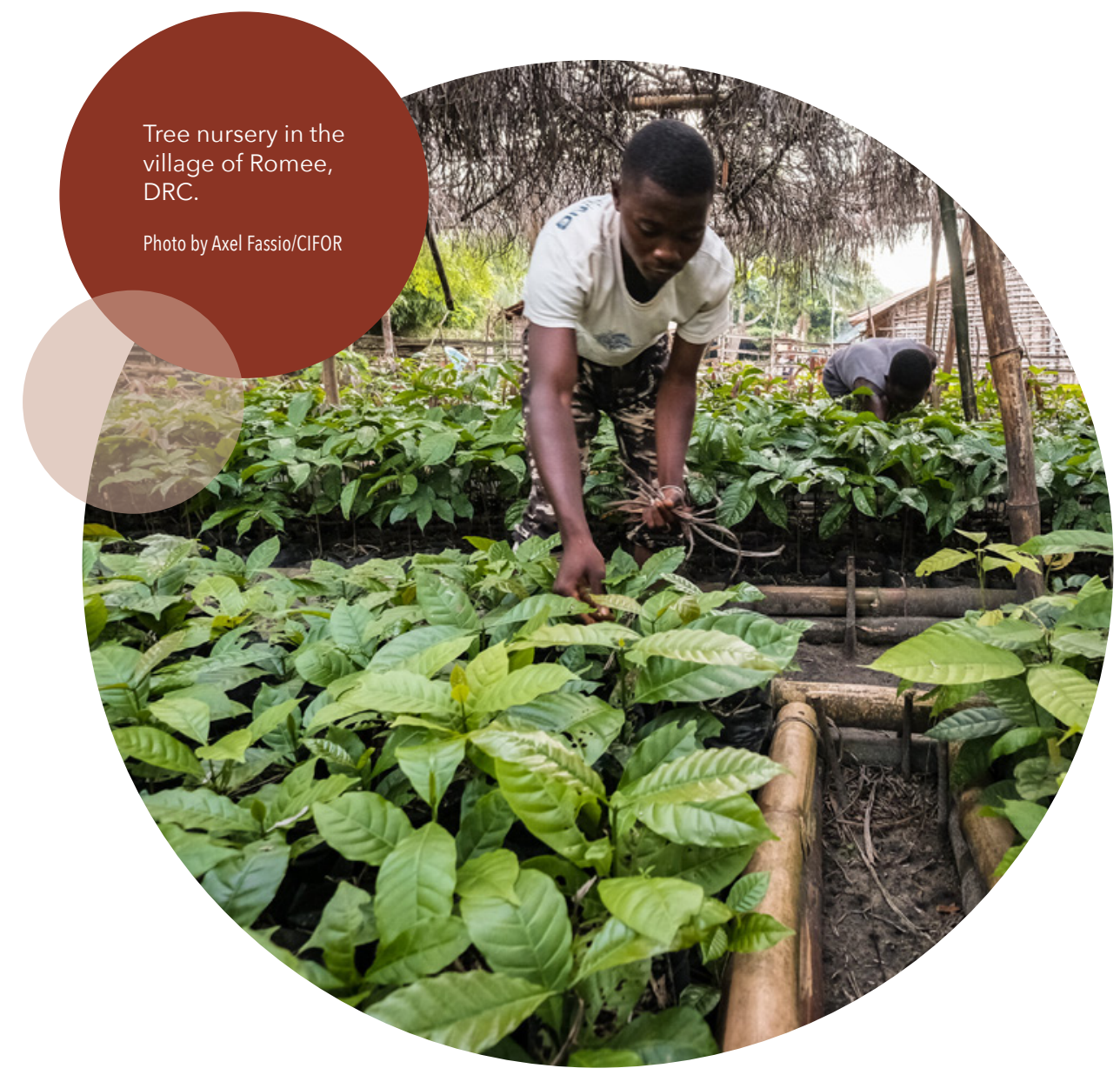


Box 1. Defining tree seed systems and understanding their importance

A tree seed system is the way that actors organize the collection and distribution of tree seeds and seedlings, from seed collection to the growers' planting of seedlings. The system can involve uncoordinated ad hoc collection of seeds from whatever sources are available or the coordinated collection of quality seeds. A well-organized system encompasses several elements:

- the basic practices of tree seeds' and seedlings' production, including the establishment and maintenance of seed sources;

- the processing and storage of seeds and the nursery propagation of seedlings;

- the distribution of seeds and seedlings to growers, with guidance on use and on the approaches needed to monitor and report on their performance;

- the roles, relationships and responsibilities of the various stakeholders who are involved in seed and seedling supply;

- the regulatory aspects of seed and seedling quality.

Seed sources - which are an integral part of the system - include forests, farmland, plantations, seed orchards and "clonal" mother blocks (these blocks are propagated as cuttings and scions rather than as seed, and are often used for the propagation of fruit trees; see Lillesø et al. 2011 for more on all these sources).

Tree seed systems can be "formal," composed of public and private organizations with specialized or designated roles in production, distribution or regulation; or "informal," made up of private households, farmers and NGOs sharing material with each other. Most formal systems have focused on enhancing productivity, but they often suffer from the shortcomings of focusing on a few (often exotic) plantation tree species. Formal systems often are also not very accessible to smallholder tree growers. Informal systems provide a broad range of products and services, and more easily reach growers, but they often rely on tree seeds of low quality. Neither formal nor informal approaches are currently meeting the need for a broad mix of tree species for planting that is well matched to planting sites and planting purposes, or for addressing both livelihood goals and environmental requirements, which are intensified by climate change. Growers often end up planting whatever tree seeds and seedlings they can find, regardless of how suboptimal - and they are often highly suboptimal - they are (Graudal and Lillesø 2007). 
Box 1. Defining tree seed systems and understanding their importance

Addressing the supply bottleneck is a key challenge to current global forest landscape restoration programmes becoming successful (Kettle et al. 2020). To improve the current situation, it is necessary to realize the potential of many more rural organizations, small-scale private nurseries and local communities to effectively participate in tree seed systems, integrating formal and informal approaches to ensure supply (Lillesø et al. 2018).

To help drive improvements in tree seed systems, FTA scientists have undertaken ex ante assessments of the benefits of good tree seed sourcing practice from both an economic and environmental perspective. For example, recent preliminary work, using a very simple bottom-up cost model, showed that the savings from better seedling establishment rates far surpassed the extra expense of quality tree seed sourcing in restoration programmes (Nef et al. 2021). This was because higher survival after out-planting reduced seedling replacement costs.

More advanced calculations indicate that modest investments to improve tree seed and seedling genetic quality will have significant quantifiable livelihood and environmental benefits. Estimates based on African Forest Landscape Restoration Initiative (AFR100) activities, for example, suggested that an extra cost per tree seedling of less than $5 \%$ invested in improving genetic quality, under modest assumptions of uptake in the use of improved planting materials, would generate more than USD 5 billion of additional income for tree growers (Lillesø et al. 2021). The same authors indicated that it could also sequester 19 million more tonnes of carbon every year, and annually save 4 million tonnes more of soil from erosion. As indicated in this Highlight publication, FTA scientists have spent considerable effort developing ways to evaluate tree seed systems in order to understand how they can be improved to better address carbon sequestration, soil erosion and other concerns, and bring greater economic benefits. 


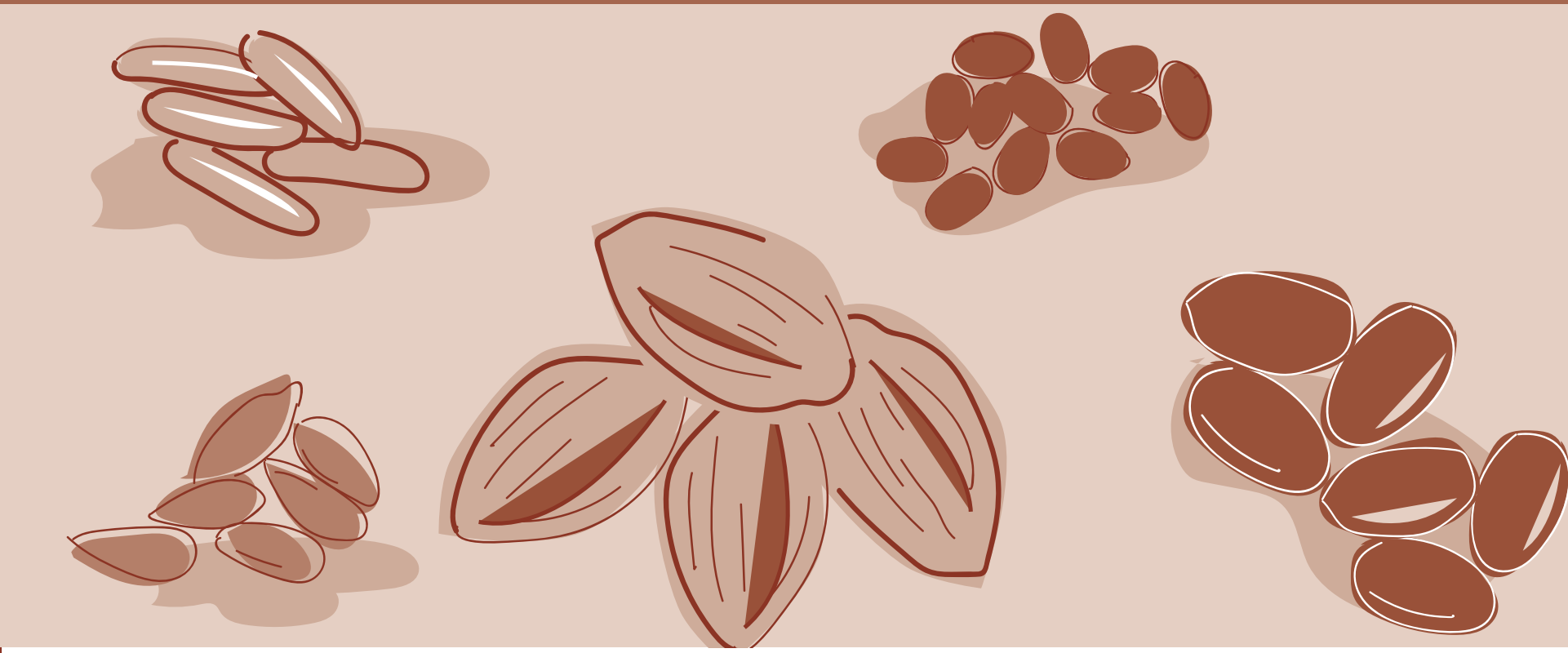

\section{Improving the availability of quality tree seed}

To upgrade tree seed systems, FTA facilitates partnerships between publicand private-sector (and formal and informal) stakeholders, and supports their innovation. It does this while engaging directly in a range of practical programmes that seek to deliver quality tree planting material at scale. The broad FTA approach to tree seed system development is being applied in Africa, Asia and Latin America, for a range of tree species that provide timber, fruit, fodder and green fertilizer. The examples presented below are designed to be replicated for wider scaling.

\subsection{Building stakeholder partnerships and model tree seed systems}

A good example of the application of the FTA approach is the ongoing Provision of Adequate Tree Seed Portfolios (PATSPO) project, implemented by ICRAF with the University of Copenhagen and Ethiopian partners (ICRAF 2021b). This project started in 2017 and has focused on improving tree seed sourcing to support Ethiopia's forest landscape restoration targets, which are the most ambitious of any country in the African Forest Landscape Restoration Initiative (AFR100 2021). The need to improve tree seed sourcing in Ethiopia was identified during earlier restoration activities, which were hampered by the lack of an efficient network for supplying tree planting material, and by the low quality and limited diversity of the tree seeds that were available (Dedefo et al. 2017; Tadesse et al. 2020). 
PATSPO has identified stakeholders in the Ethiopian tree seed sector, promoted collaboration among them, and built their capacity. It has also established breeding seedling orchards (BSOs) to supply quality tree seed; identified and registered other quality natural and planted sources of tree seed; and used low-input "diversity breeding" methods (i.e. methods designed to provide tree types that support both livelihood and environmental goals; see Graudal et al. 2021) to supply appropriate planting material. PATSPO has so far trained more than 1,000 stakeholders in tree seed collection and procurement methods; established 26 BSOs of 13 trees prioritized by communities and government in 10 different locations; and described and registered more than 100 existing seed sources of mostly indigenous trees.

Although it is too early to fully evaluate how effective PATSPO will be in improving the quality of the trees planted in Ethiopia, it has worked closely with the Ethiopian government to develop policies to support the involvement of the private and informal sectors in tree seed supply. FTA scientists' work has shown that this is important for delivering impact (see section 2.5).

Separately, but related to PATSPO, and under the umbrella of FTA, the International Bamboo and Rattan Organisation has developed collection and processing protocols for sourcing Ethiopian highland and lowland bamboo seeds that are also important for supporting landscape restoration activities in the country, but are not easily accessible to planters (Mulatu 2021).

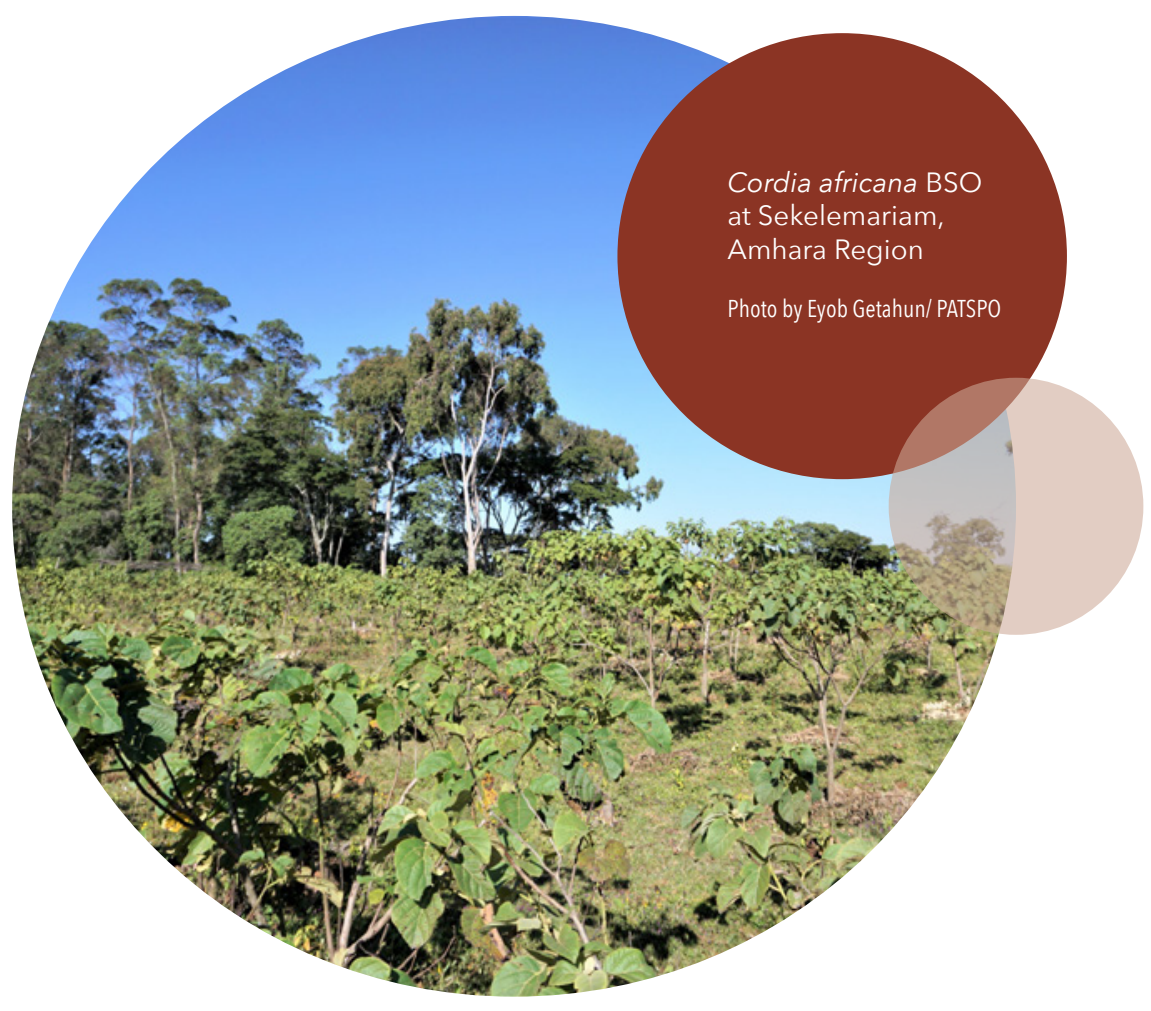




\subsection{Delivering improved orphan tree crops through supporting breeding pathways}

Orphan crops - so called because they were under-researched in the past in terms of their genetic improvement and the marketing of their use often lack seed supply capacity (McMullin et al. 2021). The African Orphan Crops Consortium (Jamnadass et al. 2020), which has involved ICRAF as a major partner since being established in 2011, is concerned with addressing production gaps for 101 lesser-used food crops that have high potential for addressing nutritional deficiencies in Africa (AOCC 2021). Specifically, the consortium develops genetic tools for the orphan crops, and sequences representative panels of varieties, genotypes, etc., to explore available genetic diversity (Hendre et al. 2019). Almost half of the plants on the AOCG action list are naturalized or indigenous food trees. This work is connected to improved seed delivery through the African Plant Breeding Academy ${ }^{1}$ (AfPBA 2021), which trains, mentors and empowers Africa's plant breeders to employ state-of-the-art approaches in their breeding work. By the end of 2020, the academy had 114 graduated alumni from 27 African nations. Collectively, these graduates were undertaking breeding work on more than 100 different crops, comprised of a mix of annual and perennial species (Jamnadass et al. 2020). AfPBA alumni conceived and helped establish the African Plant Breeders Association (APBA) for the continued professional development of plant breeders on the continent. At its inaugural meeting in Ghana in 2019, there were more than 400 participants. Measuring the impact of AOCG and AfPBA on the ground, in terms of delivering improved tree types to growers, will be a future activity of the consortium.

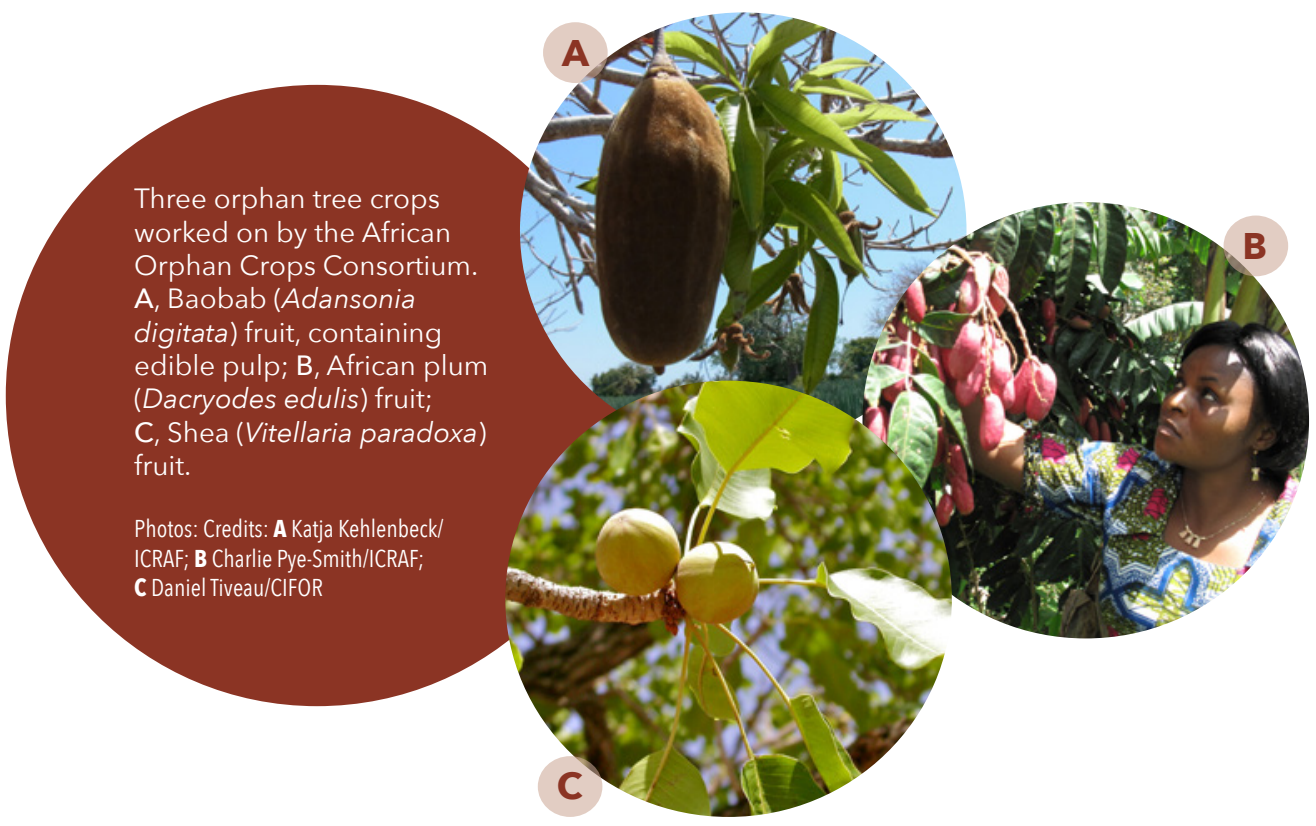

${ }^{1}$ The academy is coordinated by the University of California, Davis and is hosted by ICRAF at its headquarters in Nairobi, Kenya. 


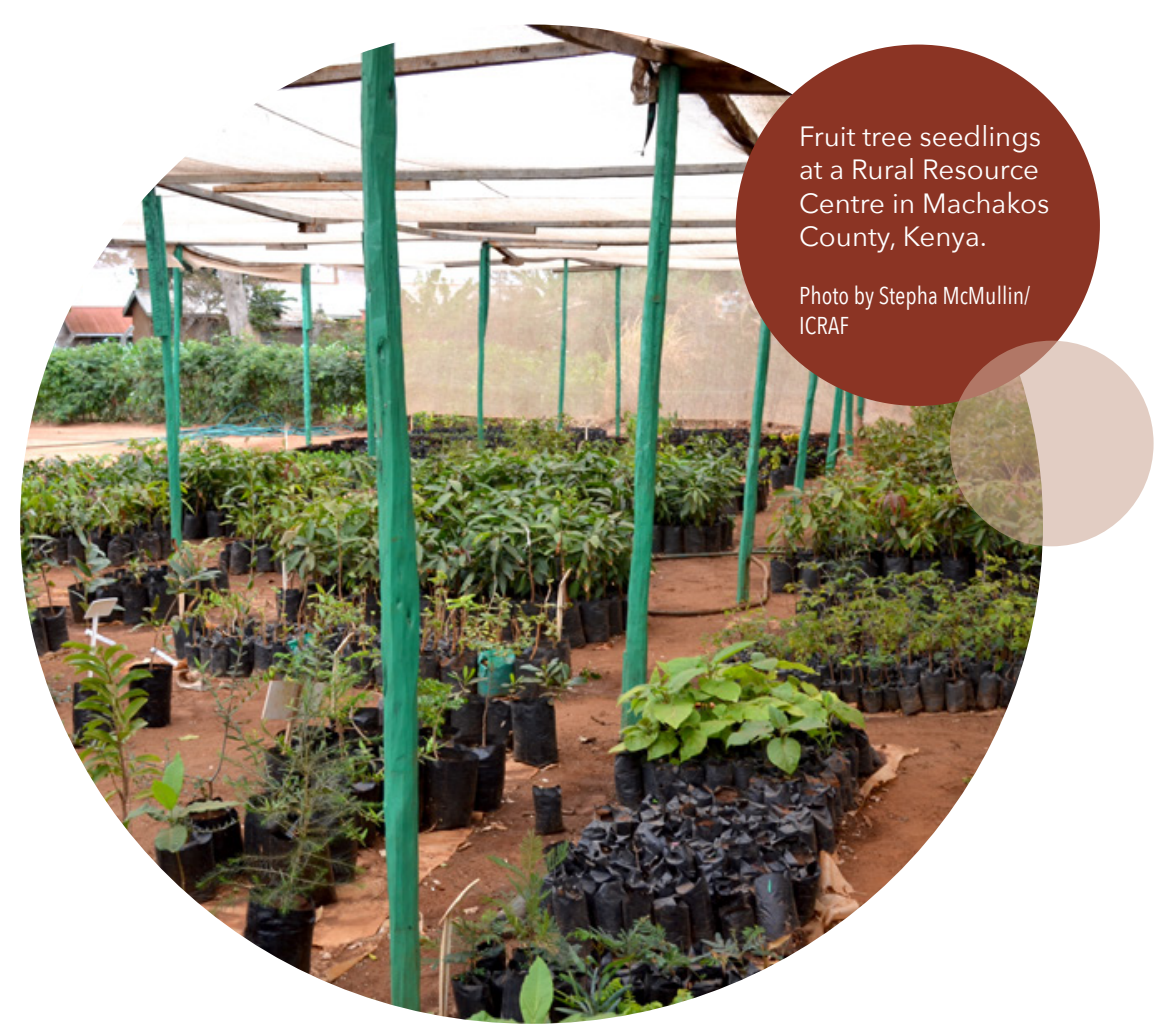

\subsection{Mainstreaming food trees through nurseries}

In principle, delivering planting material for a diversity of food trees to (potential) growers should improve rural communities' diets if they consume the foods, and should benefit local livelihoods (Lagneaux et al. 2021). For more information about work on food security and nutrition conducted within FTA, see Highlight No. 5 in this series (Ickowitz et al. 2021). The current Highlight illustrates by the examples below that there are good opportunities for scaling up food tree seedling supply with appropriate nursery support and related strategies.

One approach applied by FTA researchers to facilitate the availability and use of tree foods is to design "fruit tree portfolios" of suitable tree species that, combined with other plant foods, supply required nutrients yearround; the supply of seedlings of the trees is then supported through nursery development and other measures (McMullin et al. 2019). The design of portfolios is covered in FTA Highlight No. 5; but, in brief, it involves working with local communities to determine a recommended list of tree foods whose increased production, complementing other foods, would help fill nutrient gaps in food consumption calendars. The recommended tree foods generally come from a mix of exotic and indigenous species, the seedlings of which are made available through local tree nurseries established by farmer groups, 
nursery businesses and schools (McMullin et al. 2020; IFAD 2021). In the last decade, such portfolios have been developed for 17 locations in East Africa, and the methods involved are now being expanded to other regions.

Pilot projects in Kenya, Uganda and Ethiopia that scale up the portfolio approach have reached 6,000 farmers with training and supplied 1,800 smallholder households with a diversity of portfolio trees' seedlings. In Kenya, work with the Kenya Agricultural and Livestock Research Organization has embraced the trials, propagation and distribution of 15 of the prioritized food tree species.

The rural resource centre (RRG) is another approach that FTA researchers have developed to supply food tree seedlings. RRGs are designed to instruct people in tree propagation, farm management and other skills; and to provide processing facilities, business training and a venue where group associations can meet to market tree products and obtain farm services (Takoutsing et al. 2014; Degrande et al. 2015). Hundreds of thousands of vegetatively propagated seedlings of a diverse range of fruit trees have been distributed in Central and West Africa through RRGs and their decentralized

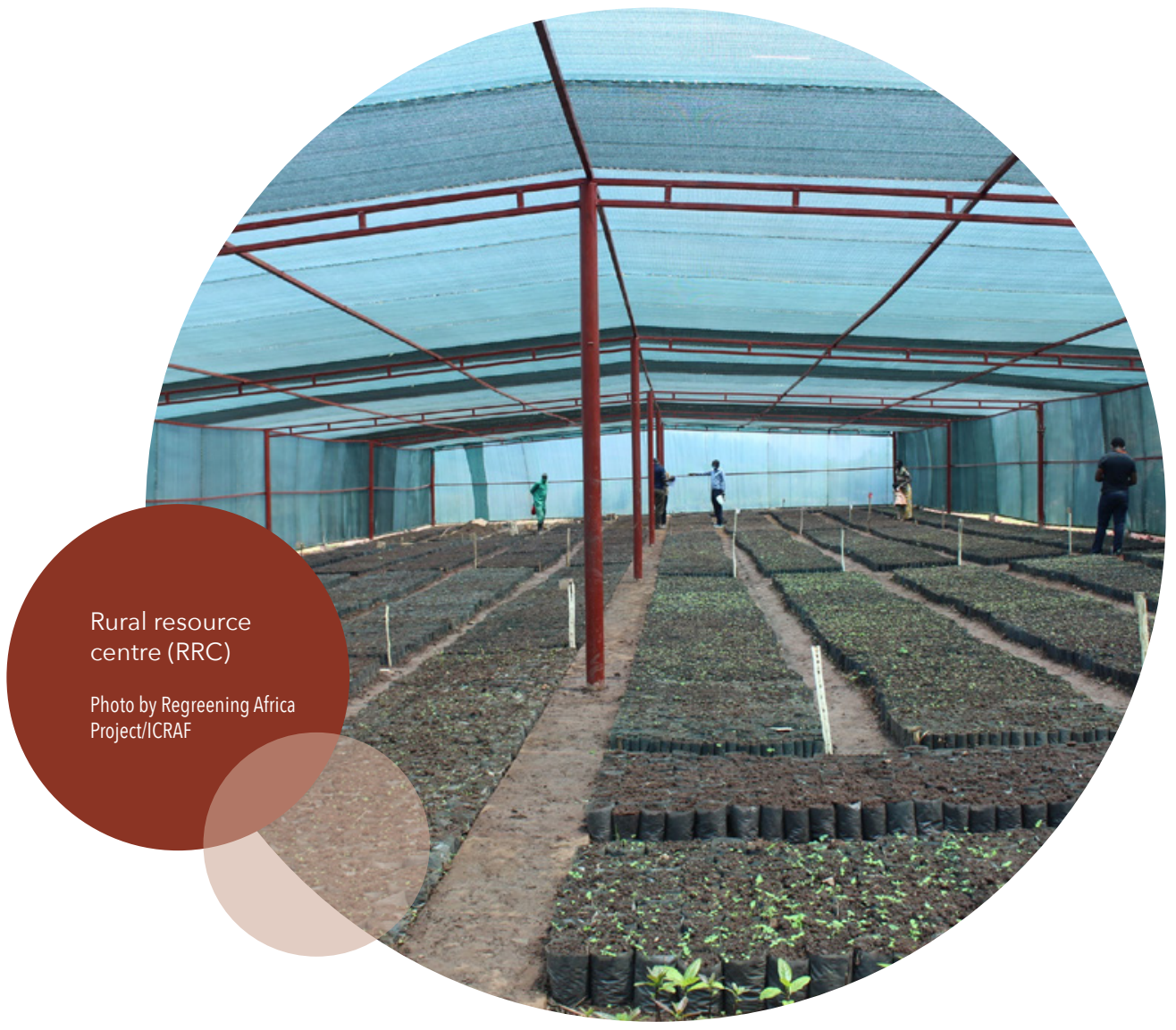


satellite nurseries, and at the same time producers have been linked to markets (Asaah et al. 2011). The approach has been used to diversify cocoa and other production systems in order to supply quality foods, sequester carbon, build resilience and take pressure off natural forest resources. Important positive impacts have been achieved for local communities in terms of income, education, youth and women's empowerment, and health, among other benefits (Leakey 2020).

FTA's tree nursery work in Viet Nam, carried out in conjunction with government-led land restoration initiatives, has also supported the scaling up of food tree seedling delivery. In this case, there has been an emphasis on the promotion of the indigenous son tra fruit tree (H'mong apple, Docynia indica). The work started with genetic improvement and propagation method development for the species, then extended to farm-based demonstration trials. More than 1,000 participants were taught about contextappropriate agroforestry systems, son tra propagation techniques, the management of on-farm tree nurseries, and value chain development (Tiep et al. 2018). Between 2016 and 2020, more than 3,000 ha of existing son tra stands were rehabilitated in Viet Nam through the use of better germplasm, while more than 6,000 ha of degraded land were planted with the fruit tree in the country's Yen Bai Province.

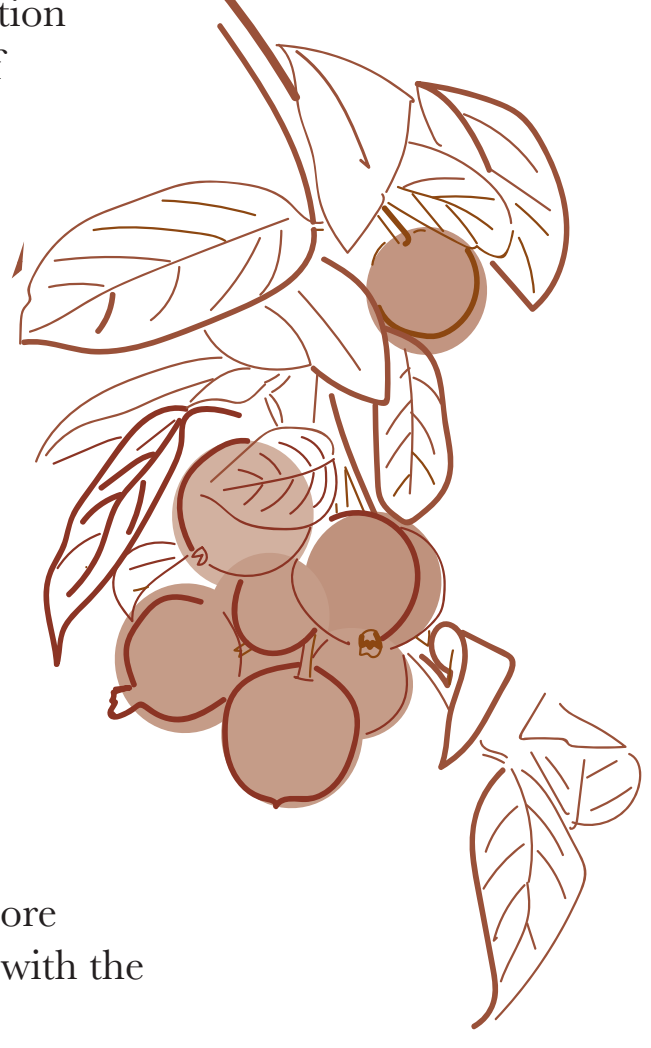

The "nurseries of excellence" (NOEL) approach that FTA scientists have applied in Indonesia has also provided farmers with the skills and infrastructure they need to implement quality seedling delivery systems for the food trees they have prioritized. The NOEL approach trains farmer leaders and farmer groups in tree nursery establishment and management, agroforestry management and market integration (Roshetko et al. 2013). In a single project that ran between 2011 and 2016, more than 300 group and individual nurseries on Sulawesi were established by farmer partners with the help of the approach. These nurseries produced more than two million quality seedlings of over 50 tree species (Roshetko et al. 2017). 


\subsection{Conserving diverse tree germplasm to support delivery and use}

Fundamental to supporting the availability of quality tree seeds to growers is that approaches are in place to conserve tree genetic resources. At ICRAF, this is an important function of the Genetic Resources Unit (GRU). The unit conserves tree genetic resources, both as seeds in its seed genebanks and as seedlings in the field genebanks it maintains with its partners. GRU's tree seed genebank in Nairobi is one of the world's most comprehensive tree seed collections that is being actively used to improve tropical tree planting; by the end of 2020 it contained 190 tree species. GRU's field genebanks, located in Africa, Asia and Latin America (see Figure 1), now feature more than 80 tree species maintained along with partners (ICRAF 2021a). These latter genebanks are particularly important for the conservation of those tree species whose seeds do not store well in seed genebanks (because the seeds die when they are dried and/or cooled).

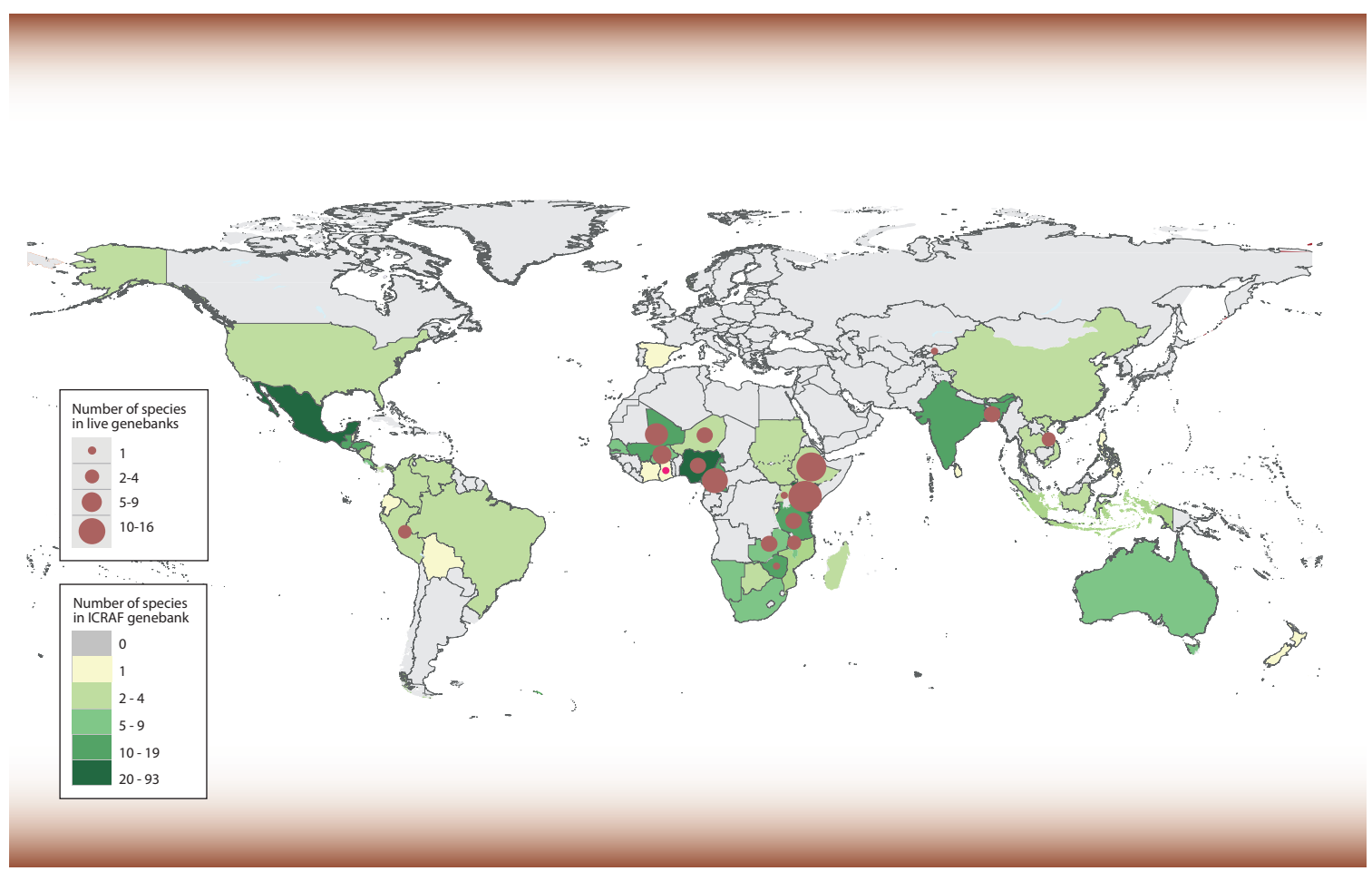

Figure 1. Map showing where ICRAF — partner field genebanks are located and where collections of tree species in the ICRAF seed genebank originated.

Note: As indicated in the key, the red circles show countries where field genebanks are situated and maintained with partners, and the number of species that they contain. The key also shows the number of species in the seed genebank in Nairobi known to be sampled from a particular country. 
Field genebanks not only have a conservation function, but are direct sources of propagules for planting. They are also observed by researchers and planters to understand more about the reproductive biology and genetic diversity of the trees, and so that they can choose the best planting material for specific locations and planting purposes (e.g. Nyoka et al. 2015a; Tiep et al. 2018). The breeding seedling orchards of the PATSPO initiative described earlier are examples of tree stands that fulfil the multiple purposes of conservation, evaluation and seed supply. For most of GRU's seed and field collections, multiple accessions are held (over 20,000 in all), so that extensive genetic variation within each tree species is retained. In the last six years, GRU has supplied more than 5,000 seed samples to users, including researchers, breeders and development practitioners.

The CATIE Forest Seed Bank (Banco de semillas forestales, or BSF) in Costa Rica is a self-sustaining commercial facility that multiplies and distributes quality seeds of (forest) tree species. It keeps 50 species in stock. Each year it reaches more than 170 clients in 20 countries, with seeds that come from its own collections, from other seed banks in the region, or from other selected sources (BSF 2021).

\subsection{Developing policies to support effective tree seed systems}

An important part of FTA's work has been to engage with national partners to help develop policies that support more effective integrated tree seed systems. This work begins by assessing, in detail, a country's existing tree seed systems, to identify bottlenecks in seed supply. In work led by Bioversity International, FTA has developed a set of indicators for this purpose, and has applied them in seven countries in Latin America. These allow the countries to identify priorities for practical steps and policy areas to strengthen their national tree seed systems (Atkinson et al. 2021). This analysis indicated opportunities for horizontal learning between countries from successful approaches, which point to the importance of active stakeholder engagement 
and incentive schemes. The same set of indicators is now being applied in western Africa and southeast Asia to help people understand tree seed systems there.

In further recent work FTA researchers developed a dynamic system approach to understand the interrelated problems that constrain the supply of good quality and site-adapted tree seeds, and applied it in Burkina Faso and the Philippines (Valette et al. 2020). Their analysis indicated that emerging options to strengthen tree seed systems for successful forest landscape restoration in those countries included better tailoring interventions to address the local context; aligning government and NGO interventions; and complementing the enforcement of regulations with strengthening the capacities of tree nurseries to produce high-quality planting material and the capacities of local institutions in resource management.

In other work, with the University of Copenhagen, FTA researchers have shown that, although each country has its specific features, there are three basic prevailing models of tree seed supply: the government model, the NGO model and the decentralized model (Lillesø et al. 2011). FTA research has shown that the decentralized model, involving community-based tree seed and seedling multiplication and delivery, is most likely to be successful in sustainably improving seed quality. However, analysis has indicated that community entrepreneurs are significantly disadvantaged by the many NGOs (practising the NGO model of supply) who distribute tree seeds and seedlings to growers without requiring payment, and who thus depress the ability to create a functioning market. The involvement of entrepreneurs in tree seed systems is also discouraged by parastatal suppliers such as national tree seed centres, practising the government model of supply. Those suppliers enjoy an inbuilt competitive advantage in selling tree seeds and seedlings in cases where they also have a government-assigned role in regulating the quality of supply across the sector as a whole.

Based on the analysis of Lillesø et al. (2011) and other similar research, FTA's policy work therefore has been directed to changing the roles of NGOs and parastatals to become more supportive of entrepreneurial suppliers of tree seed. This includes developing policy measures that encourage NGOs to provide business training and networking support to entrepreneurial suppliers of tree seeds and seedlings, and that discourage NGOs' direct involvement in supply; and measures that facilitate national tree seed centres to provide technical support and quality initial seed to entrepreneurs in seed provision, and that exclude these centres from having both productive and normative (regulatory) functions (Lillesø et al. 2018). 
This reorientation of roles is an important aspect of the integrated seed system development approach that the authors of the current Highlight piece have designed (Lillesø et al. 2021). This approach builds on previous work on implementing integrated seed systems for annual crops by considering the unique features of trees. These features include usually being field planted as seedlings rather than as seeds, high multiplication rates, and (generally) lengthy juvenile periods. As might be expected, however, the appropriate roles for different stakeholders in tree seed systems are not always as described above, so a dogmatic approach is not advisable. In Latin America, for example, modelling has indicated that additional approaches based on direct subsidies are needed to meet the requirements of restoration programmes (Cornelius and Miccolis 2018).

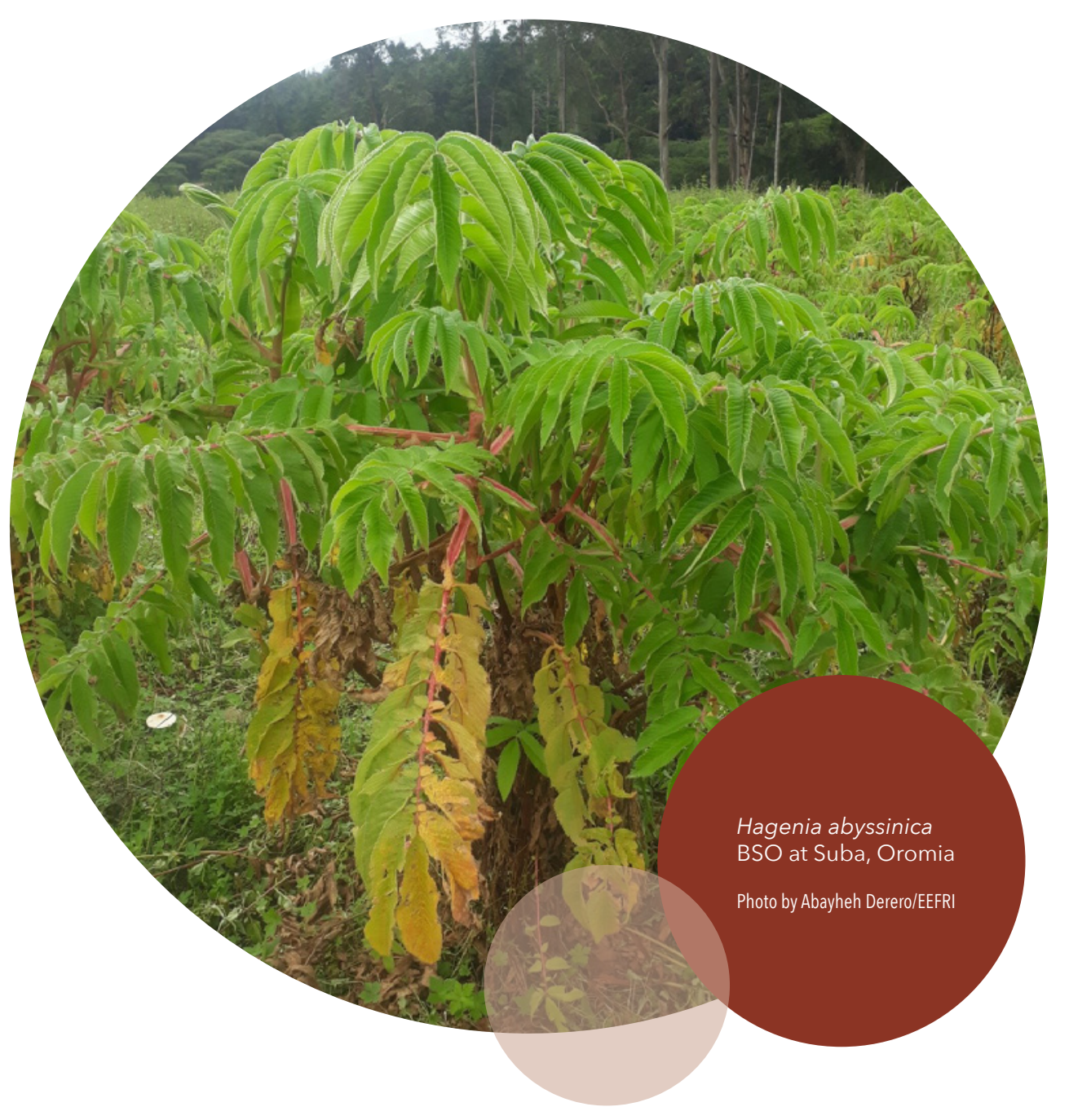




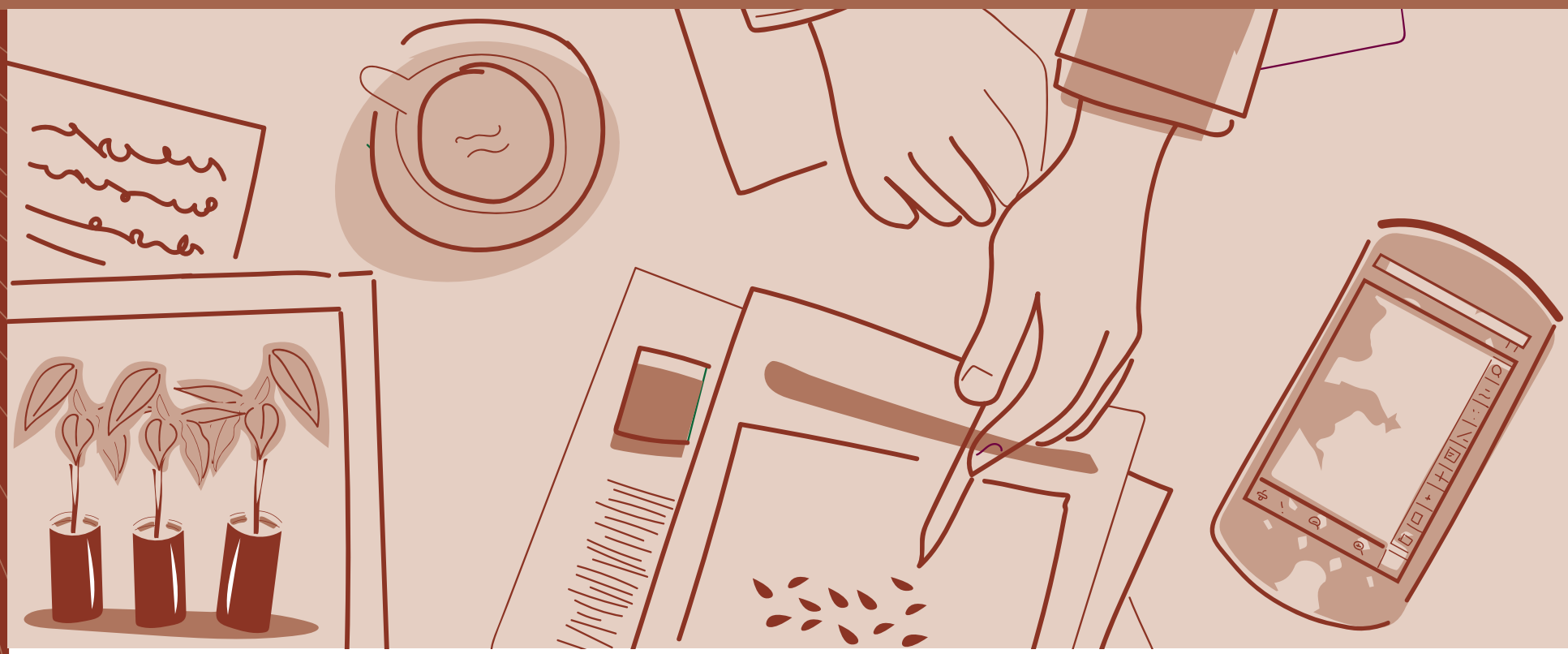

\section{Supporting better decision making in what to plant where and for what purpose}

In the last decade, to address knowledge gaps in understanding what trees to plant where, and for what purpose, FTA researchers have developed a wide range of decision-support tools. These inform more optimal planting choices that better support livelihoods and ecosystem service provision, and link tree growers with appropriate sources of planting material.

\subsection{Building information platforms to support planting choice and seed system operation}

In recent years, FTA scientists have focused on bringing existing knowledge resources together onto online platforms that provide easy access to a broad range of decision-support information. These platforms provide information on selecting trees for planting, and on how to better carry out the practices of seed collection, seed production, seed supply, tree establishment, and other procedures. One example is the Agroforestry Species Switchboard (Kindt et al. 2019), which provides access to more than 50 different webbased information sources on trees and other plants. Its particular objective is to provide information that supports both research on trees and tree-based development activities; the current version (2.0) of the switchboard provides information on more than 172,000 plant species, from across the tropics and more widely. 
Another resource is the Global Tree Knowledge Platform (GTKP) (Kindt et al. 2021a) that was released in 2021 and was one of the 50 innovation highlights showcased by CGIAR@50.2 This platform contains a wide range of tree knowledge products that are relevant to the tropics and globally. The individual products are grouped by resource type and subject area, and are designed to ensure that the right tree is planted in the right place. The platform provides access to many still-relevant older resources to guide tree seed sourcing that were developed by ICRAF and its partners, as well as new materials. Older resources include the Tree Seeds for Farmers toolkit (Kindt et al. 2006), which remains a crucial practical manual for sourcing tree seeds and seedlings by and with local communities in tropical nations. Another resource available from the GTKP is the Agroforestry Tree Domestication Primer (Dawson et al. 2012). It explains the various steps involved in bringing trees into cultivation, including how to set priorities for which tree species to plant, how to carry out participatory tree domestication, and how to source quality planting material. The primer has been downloaded more than 50,000 times.

A third platform, also released in 2021, is the Resources for Tree Planting Platform (RTPP) (Schmidt et al. 2021) that was built by the University of Copenhagen with ICRAF as part of the PATSPO project. The RTPP, which contains more than 200 individual resources from around the world, focuses specifically on tree seed system development, including practical "how to" guidelines and advice on tree seed programme design. It includes many resources from the University of Copenhagen's back catalogue of publications on the topic that are newly relevant based on the recent expansion in treebased global restoration efforts.

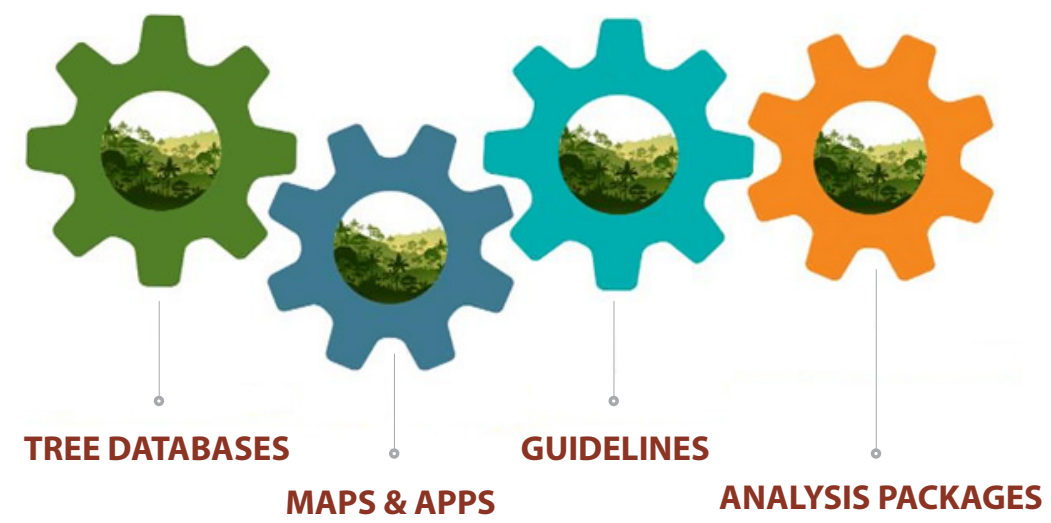

The online Global Tree Knowledge Platform contains a wide range of tree knowledge products that are organized by resource type, as shown at the entrance to the Platform (resources are also separately organized by subject area).

${ }^{2}$ https://www.cgiar.org/cgiar-at-50/ 


\subsection{Designing maps to guide appropriate planting under current and future climates}

An important resource, developed by FTA in conjunction with the University of Copenhagen and national African partners, is the vegetationmap4Africa (V4A) (van Breugel et al. 2015). The map, which took several years to develop, provides a high-resolution view of the different vegetation types of eight countries in eastern Africa and is complemented by a species selection tool for deciding what trees to plant where (Kindt et al. 2015). The documentation for V4A includes various characteristics of the different vegetation types, and information on thousands of useful tree species; it has been downloaded more than 40,000 times.

Another map-based resource developed by FTA scientists, led by Bioversity International, is the Diversity for Restoration tool (D4R), which currently covers the countries of Colombia, Peru, Ecuador, Burkina Faso and Cameroon (Thomas et al. 2017; Fremout et al. 2021b). This tool guides practitioners on tree species and seed selection for restoration use and wider tree planting efforts under current climate conditions and potential future climates. The tool uses information on geographic distributions and functional traits, and covers hundreds of tree species.

Other maps that FTA researchers have developed also focus on climate change and how it affects what trees should be planted where. The climate change atlas for Central America (de Sousa et al. 2017), for example, explains how climate change is affecting the distribution of more than 50 Central American trees, and supports planning for climate-smart seed sourcing. A similar atlas for Africa that FTA scientists' have just released covers more than 120 tree species (Kindt et al. 2021b). The comparison of current tree distributions and potential future distributions under new climatic conditions is something that FTA has done widely to support adaptive tree seed sourcing (in addition to de Sousa et al. 2017, see de Sousa et al. 2019, Marchelli et al. 2017 and Fremout et al. 2020, 2021a). For more information about work on adaptation to climate change with forests, trees and agroforestry conducted within FTA, see Highlight No. 12 in this series (Meybeck et al. 2021).

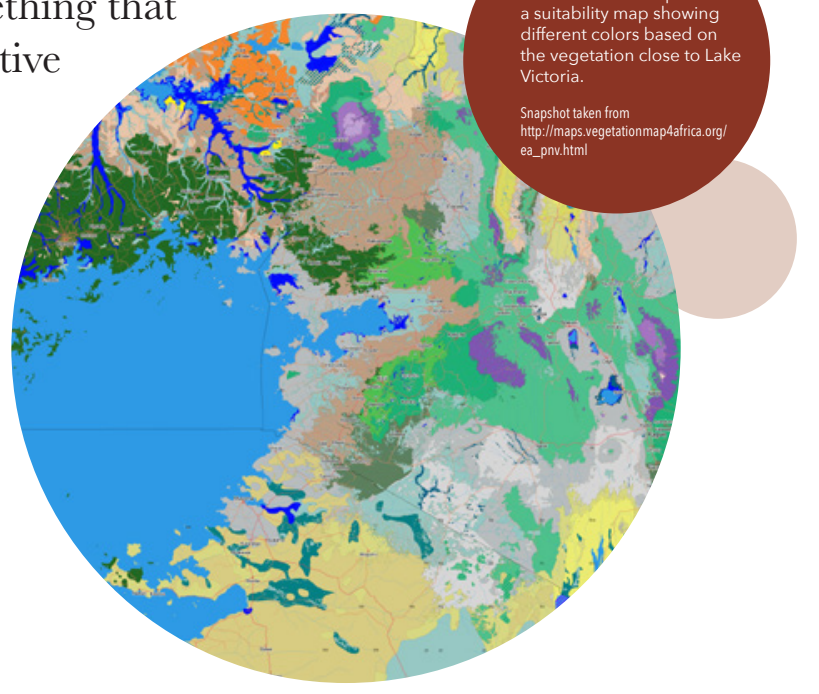




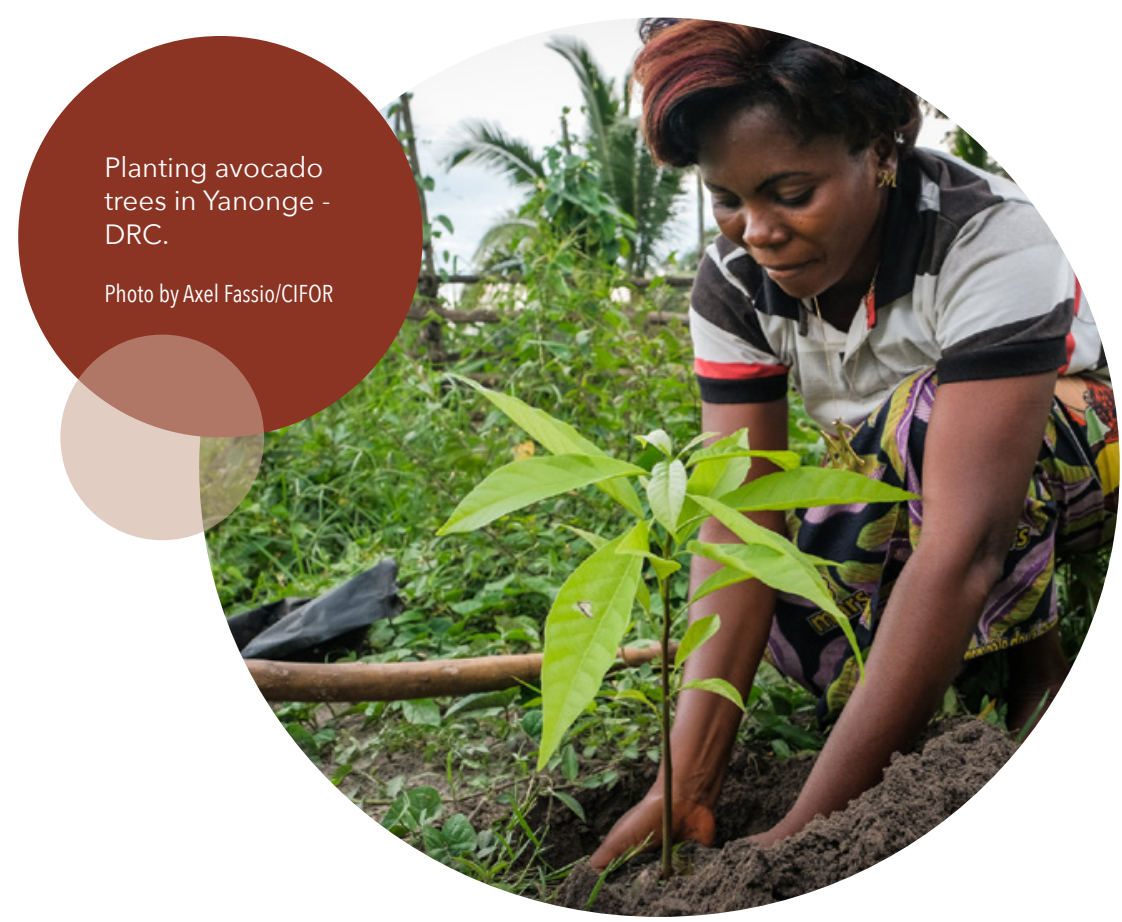

\subsection{Statistical packages to support appropriate tree planting}

FTA scientists' open-access analysis packages also support adaptive tree seed sourcing. BiodiversityR, for example, a package that ICRAF originally released in 2005 to provide a range of methods for statistically analyzing tree species' diversity (Kindt and Coe 2005), now includes methods for ensemble species suitability modelling in current and potential future climates. These methods were first added to the package in 2012 and have been updated since then (Kindt 2018). A more recent analysis package that ICRAF developed, called AlleleShift, explores changes in the distribution of genetic markers associated with climate change and helps to select tree seed sources that are matched to new environmental conditions (Kindt 2021).

These statistical tools allow growers and researchers to think into the future to the environmental conditions that will prevail when trees come into their full maturity in terms of the products and ecosystem services they provide. Trees with their long lifetimes are unique plants from this perspective, with planning needed to account for future conditions - often decades away.

The approach of developing climate-appropriate portfolios of tree diversity for productive and resilient landscapes and livelihoods uses eco-geographic data as a surrogate for genetic variation in tree species, as for a broad range of tree species it is not possible to look directly at diversity in each one (Graudal et al. 2014). The authors of the current Highlight piece have therefore 
explored whether the use of such surrogates is justified; they found it to be so, at least when tested through a meta-analysis of tree genetic variation studies in East Africa (Dawson et al. 2017).

FTA researchers have also developed statistical tools that can be used to assess the impacts of using better quality tree planting material in forest landscape restoration. These tools measure the additional carbon sequestered, the extra soil protected, and other benefits, compared to the incurred costs (Pedercini et al. 2021). The same tools allow users to determine the geographic areas that are priorities for landscape restoration, and where tree seed system infrastructure therefore needs to be built. The same authors (ibid.) demonstrated for Ethiopia a multi-indicator approach that has an advantage compared to previous prioritization methods in its broad applicability.

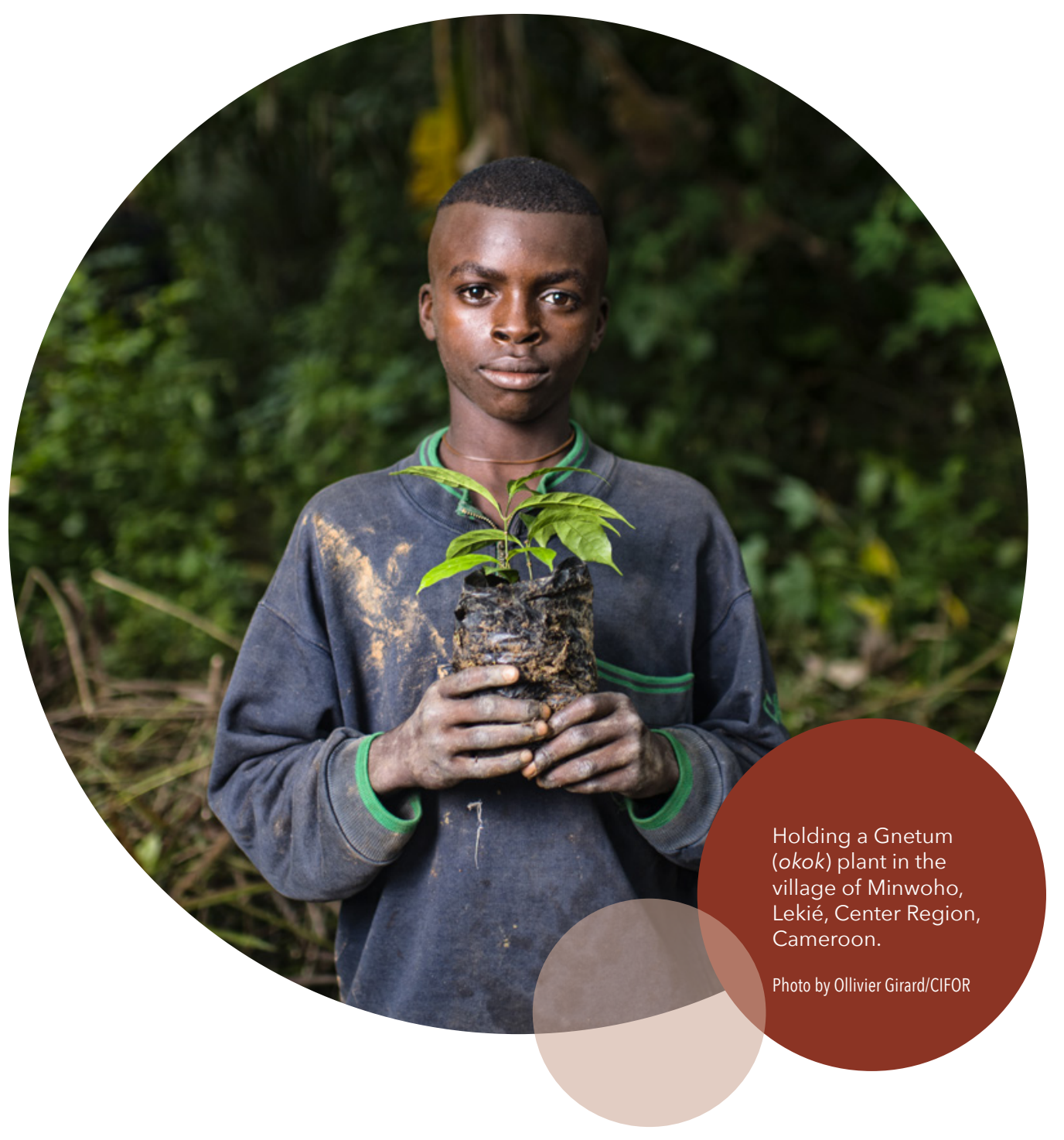




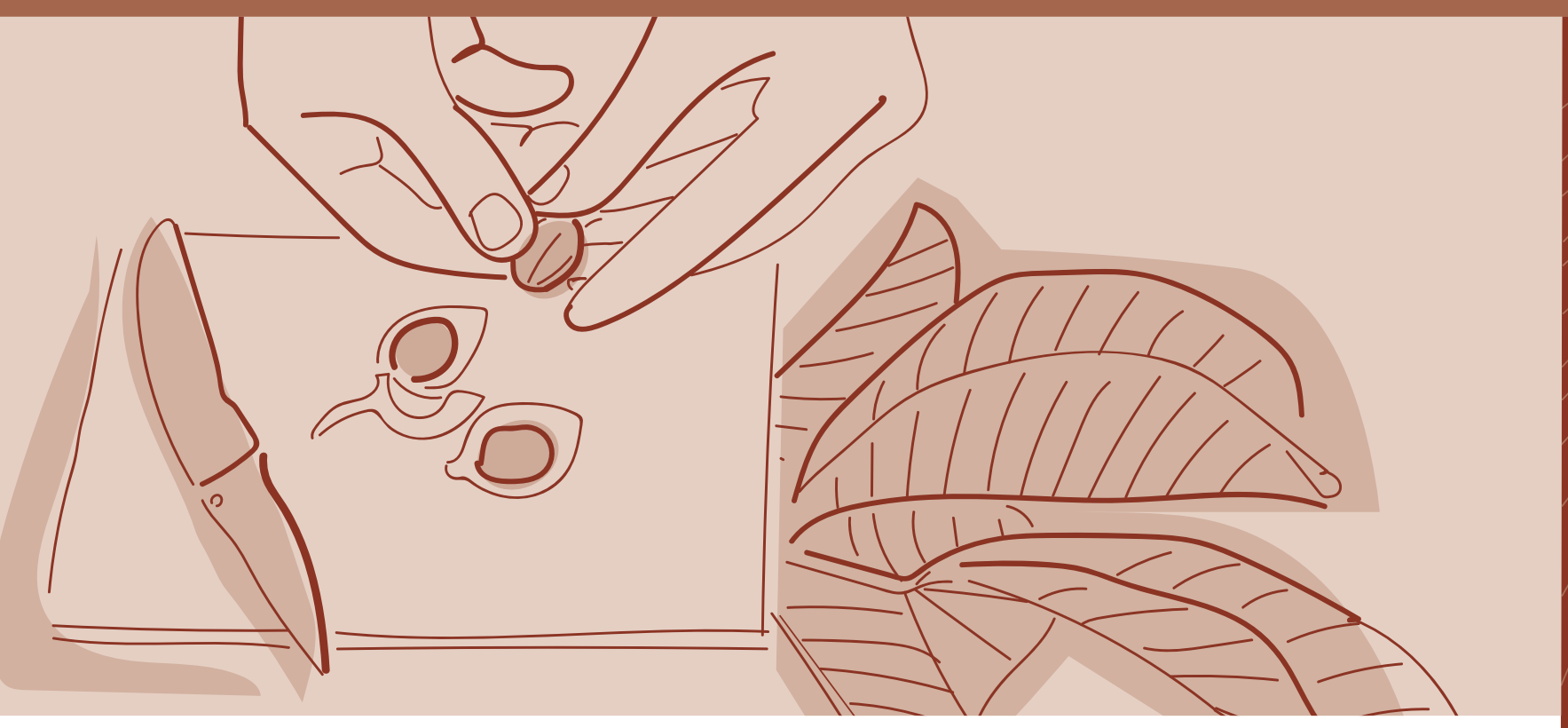

\section{Future directions}

Recently, FTA scientists have begun to explore the relative success of supplyside versus demand-side measures for mainstreaming improved genetic materials of trees and other plants. For example, a paper published earlier this year reviewed the literature, surveyed production data, and questioned stakeholders to understand the success factors for adoption of annual orphan crops in Africa (McMullin et al. 2021). This work has not yet been extended to orphan tree foods, because there are insufficient intervention case studies recorded in the literature to date to assess the situation properly (using the same methodology). The analysis of annuals showed that both productionoriented (including seed supply) and consumption-oriented (including nutritional education) interventions were frequently mentioned success factors, and it seems likely that the same would apply to orphan tree crops. A gap in testing for both annuals and perennials, however, is the absence of evaluation of the simultaneous effects of both production- and consumptionbased interventions, so information on their relative importance is limited. It is therefore recommended that future work to improve tree seed quality should evaluate both supply- and demand-side interventions together, where production and the market are seen as two parts of a single, extended and integrated value chain (Lillesø et al. 2021).

The above text provides options both for addressing the availability of tree seeds and for their better use. Recently, the authors have been exploring interventions that may help better combine these aspects, including implementing tree seed sourcing standards at the design stage of tree planting projects. This concept is based on discussions of possible solutions to address 


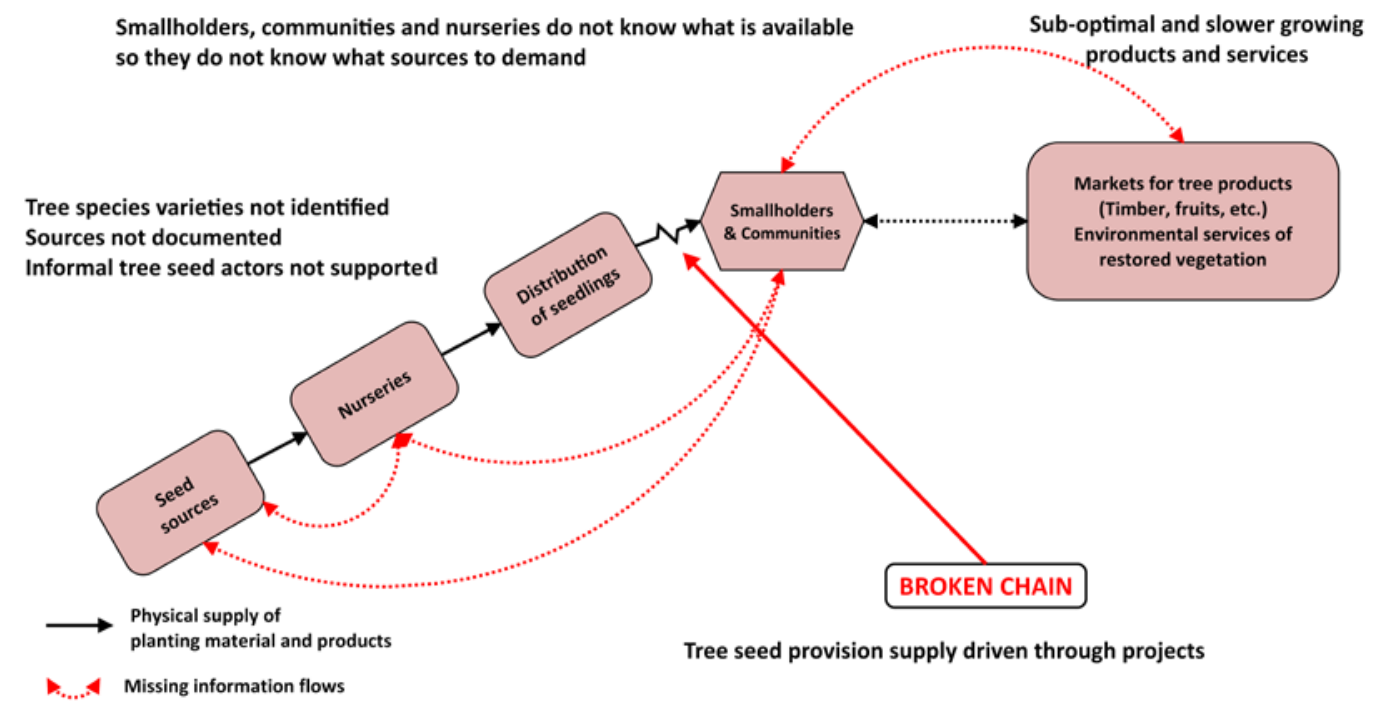

The broken value chain in agroforestry and tropical forest restoration that requires fixing (Lillesø et al. 2021)

poor tree seed sourcing practices that took place during the September 2020 online event Can tree planting save our planet? The event, which involved almost 5,000 participants, was organized by CIFOR and ICRAF in collaboration with the Global Landscapes Forum. ${ }^{3}$ The concept would require applicants asking for funding from investors to support their tree planting to explain their tree seed sourcing strategy as part of a project proposal design template. An evaluation by potential investors of the effectiveness of this strategy for realizing high seed quality would then help determine whether the project proposal should receive funding.

The authors are currently in discussion with planters, researchers and investors within the global forest landscape restoration community to understand whether this could be an effective approach to improve restoration outcomes. Initial dialogue suggests that there is indeed potential to work with investors to improve tree seed quality at the project design stage.

From a practical rather than research perspective, the primary challenge for the coming years will be to scale up the experience already gained in tree seed systems to the world's increasing forest landscape restoration commitments and to its broader tree planting initiatives, particularly through on-the-ground examples of appropriate tree seed system development and policymaker engagement. Such upscaling will provide enormous benefits in terms of 
climate change mitigation and adaptation, in the restoration of landscapes and conservation of biodiversity, and in the provision of healthy foods and other tree products that support livelihoods.

Scaling up will involve further engagement with major global initiatives such as the Bonn Challenge (2021), the UN Decade on Ecosystem Restoration 2021-2030 (UN 2021), and the Global Plan of Action (GPA) for the Conservation, Sustainable Use and Development of Forest Genetic Resources (FAO 2014a), among others. The GPA was based on the landmark State of the World's Forest Genetic Resources, published in 2014 (FAO 2014b), in which FTA scientists were very active in their contributions. FTA's work on tree seed systems addresses all four of the priority areas for action identified in the GPA: 1) access to knowledge; 2) in situ and ex situ conservation; 3) sustainable use and management; and 4) policies, institutions and capacity building. Thus, it also needs to be incorporated into the national plans of action of individual countries that are based on the GPA. 


\section{References}

AfPBA (African Plant Breeding Academy). 2021. UG Davis Plant Breeding Academy. University of California. https://pba.ucdavis.edu/PBA_in_Africa.

AFR 100 (African Forest Landscape Restoration Initiative). 2021. The African Forest Landscape Restoration Initiative. Midrand, South Africa: AFR. https://afr 100.org. AOCG (African Orphan Crops Consortium). 2021. African Orphan Crops Consortium. http://africanorphancrops.org.

Asaah EK, Tchoundjeu Z, Leakey RRB, Takousting B, NjongJ and Edang I. 2011. Trees, agroforestry and multifunctional agriculture in Cameroon. International fournal of Agricultural Sustainability 9:1 10-119. https://doi.org/10.3763/ijas.2010.0553.

Atkinson RJ, Thomas E, Roscioli F, Cornelius JP, Zamora-Cristales R, Franco Chuaire M, Alcázar C, Mesén F, Lopez H, Ipinza R, et al. 2021. Seeding resilient restoration: An indicator system for the analysis of tree seed systems. Diversity 13(8):367.

https://doi.org/10.3390/d13080367.

Bonn Challenge. 2021. The Bonn Challenge. Bonn, Germany. www.bonnchallenge.org.

BSF (Banco de Semillas Forestales). 2021. Turrialba, Costarica: Center for Tropical Agricultural Research and Education (CATIE). http://bsf.catie.ac.cr.

Cernansky R. 2021. Taking root. Science 371:666-667.

https://doi.org/10.1126/science.371.6530.666.

Cernansky R. 2018. How to plant a trillion trees. Nature 560:542-544.

https://doi.org/10.1038/d41586-018-06031-x.

Cornelius JP and Miccolis A. 2018. Can market-based agroforestry germplasm supply systems meet the needs of forest landscape restoration? New Forests 49:457-469.

https://doi.org/10.1007/s11056-018-9639-3.

Dawson I, Harwood C, Jamnadass R and Beniest J. eds. 2012. Agroforestry tree domestication: A primer. Nairobi, Kenya: World Agroforestry (ICRAF).

www.worldagroforestry.org/output/agroforestry-tree-domestication-primer.

[Available in English and Spanish versions].

Dawson IK, van Breugel P, Coe R, Kindt R, van Zonneveld M, Lillesø J-PB, Graudal L, Muchugi A, Russell J and Jamnadass R. 2017. A meta-analysis of molecular marker genetic datasets for eastern Africa trees supports the utility of potential natural vegetation maps for planning climate-smart restoration initiatives. Tree Genetics $\mathcal{E}$ Genomes 13:71. https://doi.org/10.1007/s11295-017-1155-7.

Dedefo K, Derero A, Tesfaye Y and Muriuki J. 2017. Tree nursery and seed procurement characteristics influence on seedling quality in Oromia, Ethiopia. Forests, Trees and Livelihoods 26:96-110. https://doi.org/10.1080/14728028.2016.1221365. 
Degrande A, Tchoundjeu Z, Kwidja A and Fongang Fouepe G. 2015. Rural resource centres: A community approach to extension. Global Forum for Rural Advisory Services good practice notes for extension and advisory services. Note 10. Lindau, Switzerland: GFRAS. https://www.g-fras.org/en/good-practice-notes/rural-resource-centres.html.

de Sousa K, van Zonneveld M, Holmgren M, Kindt R and Ordonez JC. 2019. The future of coffee and cocoa agroforestry in a warmer Mesoamerica. Scientific Reports 9:8828. https://doi.org/10.1038/s41598-019-45491-7.

de Sousa K, van Zonneveld M, Imbach P, Casanoves F, Kindt R and Ordonez JC. 2017. Suitability of key Central American agroforestry species under future climates: An atlas. ICRAF Occasional Paper No. 26. Nairobi, Kenya: World Agroforestry (ICRAF).

www.worldagroforestry.org/output/suitability-key-central-american-agroforestry-speciesunder-future-climates-atlas. [Available in English and Spanish versions].

Di Sacco A, Hardwick KA, Blakesley D, Brancalion PHS, Breman E, Cecilio Rebola L, Chomba S, Dixon K, Elliott S, Ruyonga G, et al. 2021. Ten golden rules for reforestation to optimize carbon sequestration, biodiversity recovery and livelihood benefits. Global Change Biology 27:1328-1348. https://doi.org/10.1111/gcb.15498.

FAO (Food and Agriculture Organization of the United Nations). 2014a. Global plan of action for the conservation, sustainable use and management of forest genetic resources. Rome: Food and Agriculture Organization of the United Nations (FAO).

https://www.fao.org/3/i3849e/i3849e.pdf.

FAO (Food and Agriculture Organization of the United Nations). 2014b. The state of the world's forest genetic resources. Rome: Food and Agriculture Organization of the United Nations (FAO) Commission on Genetic Resources for Food and Agriculture.

https://www.fao.org/3/i3825e/i3825e.pdf.

Fleischman F, Basant S, Chhatre A, Coleman EA, Fischer HW, Gupta D, Güneralp B, Kashwan P, Khatri D, Muscarella R, et al. 2020. Pitfalls of tree planting show why we need people-centered natural climate solutions. BioScience 70:947-950.

https://doi.org/10.1093/biosci/biaa094.

Fremout T, Thomas E, Bocanegra-Gonzalez KT, Aguirre-Morales CA, Morillo-Paz AT, Atkinson R, Kettle C, Gonzalez R, Alcazar-Caicedo C, Gonzalez MA, et al. 2021a. Dynamic seed zones to guide climate-smart seed sourcing for tropical dry forest restoration in Colombia. Forest Ecology and Management 490:119127.

https://doi.org/10.1016/j.foreco.2021.119127.

Fremout T, Thomas E, Gaisberger H, Van Meerbeek K, Muenchow J, Briers S, Gutierrez-Miranda CE, Marcelo-Peña JL, Kindt R, Atkinson R, et al. 2020. Mapping tree species vulnerability to multiple threats as a guide to restoration and conservation of tropical dry forests. Global Change Biology 26:3552-3568.

https://doi.org/10.1111/gcb.15028. 
Fremout T, Thomas E, Taedoumg H, Briers S, Gutiérrez-Miranda CE, Alcázar-Caicedo C, Lindau A, Kpoumie HM, Vinceti B, Kettle C, et al. 2021b. Diversity for restoration (D4R): Guiding the selection of tree species and seed sources for climate-resilient restoration of tropical forest landscapes. Fournal of Applied Ecology. https://doi.org/10.1111/1365-2664.14079.

GGW (Great Green Wall). 2021. Great Green Wall. https://www.greatgreenwall.org.

Girardin CAJ, Jenkins S, Seddon N, Allen M, Lewis SL, Wheeler GE, Griscom BW and Malhi Y. 2021. Nature-based solutions can help cool the planet - if we act now. Nature 593:191-194. https://doi.org/10.1038/d41586-021-01241-2.

Graudal L and Lillesø J-PB. 2007. Experiences and future prospects for tree seed supply in agricultural development support, based on lessons learnt in Danida-supported programmes 1965-2005. Copenhagen: Ministry of Foreign Affairs.

https://www.worldagroforestry.org/publication/experiences-and-future-prospects-treeseed-supply-agricultural-development-support.

Graudal L, Aravanopoulos F, Bennadji Z, Changtragoon S, Fady B, Kjær ED, Loo J, Ramamonjisoa L and Vendramin GG. 2014. Global to local genetic diversity indicators of evolutionary potential in tree species within and outside forests. Forest Ecology and Management 333:35-51. https://doi.org/10.1016/j.foreco.2014.05.002.

Graudal L, Dawson IK, Hale I, Powell W, Hendre P and Jamnadass R. 2021. 'Systems approach' plant breeding illustrated by trees. Trends in Plant Science. https://doi.org/10.1016/j.tplants.2021.09.009.

Griscom BW, Adams J, Ellis PW, Houghton RA, Lomax G, Miteva DA, Schlesinger WH, Shoch D, SiikamäkiJV, Smith P, et al. 2017. Natural climate solutions. PNAS 114:1164511650. https://doi.org/10.1073.

Guariguata MR, Atmadja S, Baral H, Boissière M, Brady M, Chomba S, Cronkleton P, Djoudi H, Duchelle A, Duguma LA, et al. 2021. Forest and Landscape Restoration. FTA Highlights of a Decade 2011-2021 series. Highlight No. 4. Bogor, Indonesia: The GGIAR Research Program on Forests, Trees and Agroforestry (FTA). https://doi.org/10.17528/cifor/008214.

Hendre PS, Muthemba S, Kariba R, Muchugi A, Fu Y, Chang Y, Song B, Liu H, Liu M, Liao X, et al. 2019. African Orphan Crops Consortium (AOCG): Status of developing genomic resources for African orphan crops. Planta 250:989-1003. https://doi.org/10.1007/s00425-019-03156-9.

Holl KD and Brancalion PHS. 2020. Tree planting is not a simple solution. Science 368:580-581. https://doi.org/10.1126/science.aba8232.

Ickowitz A, McMullin S, Dawson IK, Sunderland T, Powell B, Nurhasan M, Jamnadass R, Meybeck A and Gitz V. 2021. Food Security and Nutrition. FTA Highlights of a Decade 2011-2021 series. Highlight No. 5. Bogor, Indonesia: The GGIAR Research Program on Forests, Trees and Agroforestry (FTA). https://doi.org/10.17528/cifor/008215. 
ICRAF (World Agroforestry). 2021a. Genetic Resources Unit. Nairobi, Kenya: World Agroforestry (ICRAF). http://apps.worldagroforestry.org/products/grunew.

ICRAF (World Agroforestry). 2021b. Provision of adequate tree seed portfolio in Ethiopia. http:// www.worldagroforestry.org/project/provision-adequate-tree-seed-portfolio-ethiopia.

IFAD (International Fund for Agricultural Development). 2021. Catalogue of innovations: Enhancing smallholder agriculture and food system resilience. Nairobi, Kenya: IFAD East and Southern Africa Region. https://www.ifad.org/documents/38714170/39155702/ Innovations_Catalogue_FINAL.pdf/31df187d-63f4-f2e6-a3b4-2d760d6d249e.

Jalonen R, Valette M, Boshier D, Duminil J and Thomas E. 2018. Forest and landscape restoration severely constrained by a lack of attention to the quantity and quality of tree seed: Insights from a global survey. Conservation Letters 11(4):e12424.

https://doi.org/10.1111/conl.12424.

Jamnadass R, Mumm RH, Hale I, Hendre P, Muchugi A, Dawson IK, Powell W, Graudal L, Yana-Shapiro H, Simons AJ, et al. 2020. Enhancing African orphan crops with genomics. Nature Genetics 52:356-360. https://doi.org/10.1038/s41588-020-0601-x.

Jones B. 2021. The surprising downsides to planting trillions of trees. Vox. https://www. vox.com/down-to-earth/22679378/tree-planting-forest-restoration-climate-solutions.

Kettle CJ, Atkinson R, Boshier D, Ducci F, Dawson I, Ekué M, Elias M, Graudal L, Jalonen R, Koskela J, et al. 2020. Priorities, challenges and opportunities for supplying tree genetic resources. Unasylva 71(1):51-61. https://cgspace.cgiar.org/bitstream/ handle $/ 10568 / 1$ 10689/Kettleetal2020.pdf? sequence=3\&isAllowed $=\mathrm{y}$.

Kindt R. 2021. Allele Shift: An R package to predict and visualize population-level changes in allele frequencies in response to climate change. Peerf 9:e11534.

https://doi.org/10.7717/peerj.11534.

Kindt R. 2018. Ensemble species distribution modelling with transformed suitability values. Environmental Modelling \& Software 100:136-145.

https://doi.org/10.1016/j.envsoft.2017.11.009.

Kindt R and Coe R. 2005. Tree diversity analysis: A manual and software for common statistical methods for ecological and biodiversity studies. Nairobi, Kenya: World Agroforestry (ICRAF). https://www.worldagroforestry.org/output/tree-diversity-analysis.

Kindt R, Dawson I, Graudal L and Jamnadass R. 2021a. The global tree knowledge platform: A collection of interlinked databases, maps, guidelines, $R$ packages and other decision-support tools to guide planting of the 'right tree in the right place for the right purpose.' Nairobi, Kenya: World Agroforestry (ICRAF). www.worldagroforestry.org/tree-knowledge.

Kindt R, Abiyu A, Borchardt P, Dawson I, Demissew S, Graudal L, Jamnadass R, Lillesø J-PB, Moestrup S, Pedercini F, et al. 2021b. A climate change atlas for Africa of tree species prioritized for forest landscape restoration in Ethiopia. Nairobi, Kenya: World Agroforestry (ICRAF). https://atlas.worldagroforestry.org/. 
Kindt R, John I, Ordonez J, Dawson I, Lillesø J-PB, Muchugi A, Graudal L and Jamnadass R. 2019. Agroforestry Species Switchboard: A synthesis of information sources to support tree research and development activities. Version 2.0. Nairobi, Kenya: World Agroforestry (ICRAF). http://www.worldagroforestry.org/products/switchboard.

Kindt R, Lillesø J-PB, Mbora A, Muriuki J, Wambugu C, Frost W, Beniest J, Aithal A, Awimbo J, Rao S, et al. 2006. Tree seeds for farmers: A toolkit and reference source. Nairobi, Kenya: World Agroforestry (ICRAF). https://www.worldagroforestry.org/output/treeseeds-farmers-toolkit-and-reference-source.

Kindt R, van Breugel P, Orwa C, Lillesø JPB, Jamnadass R and Graudal L. 2015. Useful tree species for Eastern Africa: A species selection tool based on the Vegetationmap4africa map. Version 2.0. Nairobi, Kenya: World Agroforestry; Copenhagen, Denmark: Forest \& Landscape Denmark. https://vegetationmap4africa.org/Species/Species_selection_tool.html.

Lagneaux E, Jansen M, Quaedvlieg J, Zuidema PA, Anten NPR, García Roca MR, Corvera-Gomringer R and Kettle CJ. 2021. Diversity bears fruit: Evaluating the economic potential of undervalued fruits for an agroecological restoration approach in the Peruvian Amazon. Sustainability 1(8):4582. https://doi.org/10.3390/su13084582.

Leakey RRB. 2020. A re-boot of tropical agriculture benefits food production, rural economies, health, social justice and the environment. Nature Food (1):260-265. https://doi.org/10.1038/s43016-020-0076-z.

Lillesø J-PB, Dawson IK, Graudal L and Jamnadass R. 2021. Quality seed for tree planting: Supporting more effective agroforestry and forest landscape restoration by learning from crop Integrated Seed System Development. ICRAF Policy Brief No. 54. Nairobi, Kenya: World Agroforestry (ICRAF). https://www.worldagroforestry.org/publication/quality-seed-tree-plantingsupporting-more-effective-agroforestry-and-forest-landscape.

Lillesø J-PB, Graudal L, Moestrup S, Kjær ED, Kindt R, Mbora A, Dawson I, Muriuki J, Ræbild A and Jamnadass R. 2011. Innovation in input supply systems in smallholder agroforestry: Seed sources, supply chains and support systems. Agroforestry Systems 83:347359. https://doi.org/10.1007/s10457-011-9412-5.

Lillesø J-PB, Harwood C, Derero A, Graudal L, Roshetko JM, Kindt R, Moestrup S, Omondi WO, Holtne N, Mbora A, et al. 2018. Why institutional environments for agroforestry seed systems matter. Development Policy Review 36: O89-O1 12. https://doi.org/10.1111/dpr.12233.

Marchelli P, Thomas E, Azpilicueta MM, van Zonneveld M and Gallo L. 2017. Integrating genetics and suitability modelling to bolster climate change adaptation planning in Patagonian Nothofagus forests. Tree Genetics \& Genomes 13:119. https://link.springer.com/article/10.1007/s11295-017-1201-5.

McMullin S, Njogu K, Wekesa B, Gachuiri A, Ngethe E, Stadlmayr B, Jamnadass R and Kehlenbeck K. 2019. Developing fruit tree portfolios that link agriculture more effectively with nutrition and health: A new approach for providing year-round micronutrients to smallholder farmers. Food Security 11:1355-1372.

https://doi.org/10.1007/s12571-019-00970-7. 
McMullin S, Stadlmayr B, Mausch K, Revoredo-Giha C, Burnett F, Guarino L, Brouwer ID, Jamnadass R, Graudal L, Powell W, et al. 2021. Determining appropriate interventions to mainstream nutritious orphan crops into African food systems. Global Food Security 28:100465. https://doi.org/10.1016/j.gfs.2020.100465.

McMullin S, Stadlmayr B, Ngethe E, Wekesa B, Njogu K, Gachuiri A, Mbaya B, Katiwa A and Jamnadass R. 2020. Trees nurture nutrition: An insight on how to integrate locally available food tree and crop species in school gardens. In Hunter D, Monville-Oro E, Burgos B, Nyhria Roel C, Calub BM, Gonsalves J, Lauridsen N. eds. Agrobiodiversity, School Gardens and Healthy Diets. Abingdon-on-Thames, UK: Routledge, pp. 86-104.

https://www.bioversityinternational.org/e-library/publications/detail/agrobiodiversityschool-gardens-and-healthy-diets/.

Meybeck A, Licona Mansur C, Gitz V, Dawson IK, Martius C, Kindt R, Louman B, Houria D, Duguma LA, Sommariba E, et al. 2021. Adaptation to Climate Change with Forests, Trees and Agroforestry. FTA Highlights of a Decade 2011-2021 series. Highlight No. 12. Bogor, Indonesia: The CGIAR Research Program on Forests, Trees and Agroforestry (FTA). https://doi.org/10.17528/cifor/008222.

Mulatu Y. 2021. Bamboo seed sourcing/selection study in Ethiopia. Working Paper. Beijing, China: International Bamboo and Rattan Organisation. https://www.inbar.int/ resources/inbar_publications/bamboo-seed-sourcing-selection-study-in-ethiopia.

Nef DP, Gotor E, Wiederkehr GG, Zumwald M and Kettle CJ. 2021. Initial investment in diversity is the efficient thing to do for resilient forest landscape restoration. Frontiers in Forests and Global Change 3:615682. https://doi.org/10.3389/ffgc.2020.615682.

Nyoka BI, Chanyenga T, Mng'omba SA, Akinnifesi FK and Sagona W. 2015a. Variation in growth and fruit yield of populations of Sclerocarya birrea (A. Rich.) Hochst. Agroforestry Systems 89:397-407. https://doi.org/10.1007/s10457-014-9774-6.

Nyoka BI, Roshetko J, Jamnadass R, Muriuki J, Kalinganire A, Lillesø J-P B, Beedy T and Cornelius J. 2015b. Tree seed and seedling supply systems: A review of the Asia, Africa and Latin America models. Small-scale Forestry 14:171-191. https://doi.org/10.1007/s11842-014-9280-8.

Pedercini F, Dawson IK, Kindt R, Tadesse W, Moestrup S, Abiyu A, Lillesø J-PB, van Schoubroeck F, McMullin S, Carsan S, et al. 2021. Priority landscapes for tree-based restoration in Ethiopia. Working Paper No. 320. Nairobi, Kenya: World Agroforestry. https://dx.doi.org/10.5716/WP21037.PDF

Rosenstock TS, Dawson IK, Aynekulu E, Chomba S, Degrande A, Fornace K, Jamnadass R, Kimaro A, Kindt R, Lamanna C, et al. 2019. A planetary health perspective on agroforestry in Sub-Saharan Africa. One Earth (1):330-344. https://doi.org/10.1016/j.oneear.2019.10.017. 
Roshetko JM, Dahlia L, Purwanto E, Moeliono M, Widayati A, Purnomosidhi P, Mahrizal, Wau D, Perdana A, Martini E, et al. 2017. Agroforestry and forestry in Sulawesi: Linking knowledge with action (AgFor) project. End of Project Report. Bogor, Indonesia: World Agroforestry (ICRAF) Southeast Asia Regional Programme, Center for International Forestry Research (CIFOR) and Operation Wallacea Trust; Makassar, Indonesia: Faculty of Forestry, Hasanuddin University.

Roshetko JM, Dawson IK, Urquiola J, Lasco RD, Leimona B, Weber JC, Bozzano M, Lillesø J-PB, Graudal L and Jamnadass R. 2018. To what extent are genetic resources considered in environmental service provision? A case study based on trees and carbon sequestration. Climate and Development 10:755-768.

https://doi.org/10.1080/17565529.2017.1334620.

Roshetko JM, Idris N, Purnomosidhi P, Zulfadhli T and Tarigan J. 2013. Farmer extension approach to rehabilitate smallholder fruit agroforestry systems: The "Nurseries of excellence (NOEL)" program in Aceh, Indonesia. Acta Horticulturae 975:649-656. https://doi.org/10.17660/ActaHortic.2013.975.81.

Schmidt LH, Barsotti D, Moestrup S, Abiyu A, Graudal L, Jamnadass R, Dawson IK, Lillesø J-PB, Kindt R and Robbins AMJ. 2021. The resources for tree planting platform: Delivering high-quality tree-planting material to growers. Copenhagen, Denmark: University of Copenhagen and Nairobi, Kenya: World Agroforestry (ICRAF). https://tree.worldagroforestry.org.

Tadesse W, Worku A and Kang HS. eds. 2020. Regreening Ethiopia. Daejeon, Republic of Korea: Korea Forest Service.

Takoutsing B, Tchoundjeu Z, Degrande A, Asaah E and Tsobeng A. 2014. Scaling-up sustainable land management practices through the concept of the rural resource centre: Reconciling farmers' interests with research agendas. Fournal of Agricultural Education and Extension 20:463-483. https://doi.org/10.1080/1389224X.2014.913984.

Thomas E, Alcazar C, Moscoso Higuita LG, Vasquez A, Osorio LF, Salgado-Negret B, Gonzalez M, Parra-Quijano M, Bozzano M, LooJ, et al. 2017. The importance of species selection and seed sourcing in forest restoration for enhancing adaptive capacity to climate change: Colombian tropical dry forest as a model. CBD Technical Series 89:122-132. https://www.bioversityinternational.org/e-library/publications/detail/ the-importance-of-species-selection-and-seed-sourcing-in-forest-restoration-for-enhancingadaptive-p/.

Thomas E, Jalonen R, Loo J, Boshier D, Gallo L, Gavers S, Bordács S, Smith P and Bozzano M. 2014. Genetic considerations in ecosystem restoration using native tree species. Forest Ecology and Management 333:66-75. https://doi.org/10.1016/j. foreco.2014.07.015.

Tiep HV, Thuong PH, Nguyen L, Lua HT, Thuan VV, Kieu TL, Carsan S, Degrande A, Catacutan D and Harwood C. 2018. Domestication of Docynia indica in Vietnam. Forests, Trees and Livelihoods 27:230-242. https://doi.org/10.1080/14728028.2018.1511480. 
UN (United Nations). 2021. Preventing, halting and reversing the degradation of ecosystems worldwide. The UN Decade on Ecosystem Restoration. New York: UN. www.decadeonrestoration.org.

Valette M, Vinceti B, Gregorio N, Bailey A, Thomas E and Jalonen R. 2020. Beyond fixes that fail: Identifying sustainable improvements to tree seed supply and farmer participation in forest and landscape restoration. Ecology and Society 25(4):30.

https://doi.org/10.5751/ES-12032-250430.

van Breugel P, Kindt R, Lillesø J-PB, Bingham M, Demissew S, Dudley C, Friis I, Gachathi F, Kalema J, Mbago F, et al. 2015. Potential natural vegetation of eastern Africa (Burundi, Ethiopia, Kenya, Malawi, Rwanda, Tanzania, Uganda and Zambia). Version 2.0. Copenhagen, Denmark: Forest \& Landscape Denmark, and Nairobi, Kenya: World Agroforestry (ICRAF). https://vegetationmap4africa.org.

Vinceti B, Thomas E, Jalonen R, Guariguata MR, Snook L, Gaisberger H, Dawson IK, Jamnadass R and Kettle C. 2021. Conservation of Tree Biodiversity and Sustainable Forest Management. FTA Highlights of a Decade 2011-2021 series. Highlight No.3. Bogor, Indonesia: The CGIAR Research Program on Forests, Trees and Agroforestry (FTA). https://doi.org/10.17528/cifor/008213.

Williams T. 2020. Planting trees won't stop climate change. Slate.

https://slate.com/technology/2020/05/trees-dont-stop-climate-change.html. 


\section{The FTA Highlights series}

1. Introduction: Ten Years of Forests, Trees and Agroforestry Research in Partnership for Sustainable Development

\section{Tree Seed and Seedling Systems for Resilience} and Productivity

3. Conservation of Tree Biodiversity and Sustainable Forest Management

4. Forest and Landscape Restoration

5. Food Security and Nutrition

6. Wild Meat

7. Trees on Farms to Improve Livelihoods and the Environment

8. Biomass, Bioenergy and Biomaterials

9. Improving Rural Livelihoods through Supporting Local Innovation at Scale

10. Sustainable Value Chains, Finance and Investment in Forestry and Tree Commodities

11. REDD+: Combating Glimate Change with Forest Science

12. Adaptation to Climate Change with Forests, Trees and Agroforestry

13. Multifunctional Landscapes for Sustainable Development

14. Governing Forests, Trees and Agroforestry for Delivering on the SDGs

15. Advancing Gender Equality and Social Inclusion

16. Capacity Development

17. Monitoring, Evaluation, Learning and Impact Assessment

18. The Way Forward

This list represents the order of the volumes in the series and not the time sequence of publication. 



\section{Tree Seed and Seedling Systems for Resilience and Productivity}

Over the last decade, the CGIAR Program on Forests, Trees and Agroforestry (FTA) has undertaken innovative basic and applied research across different scientific disciplines on tree seed systems. FTA's work supports climate change mitigation and adaptation, restores landscapes and conserves biodiversity, and provides healthy foods and other products for local and global communities. This publication presents key FTA outputs on seeds and seed systems from 2011 to 2021.

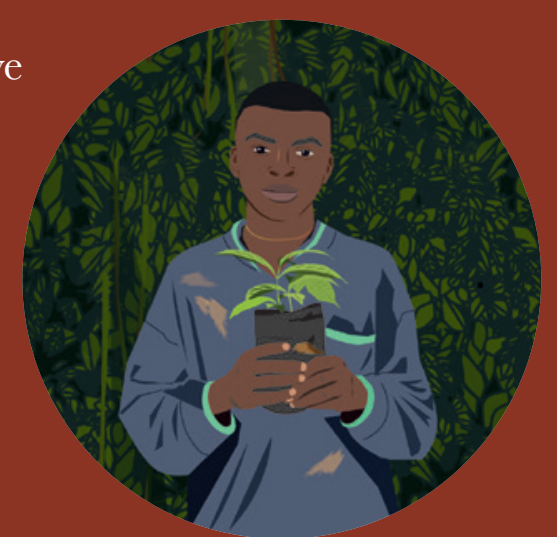

DOI: $10.17528 /$ cifor $/ 008212$
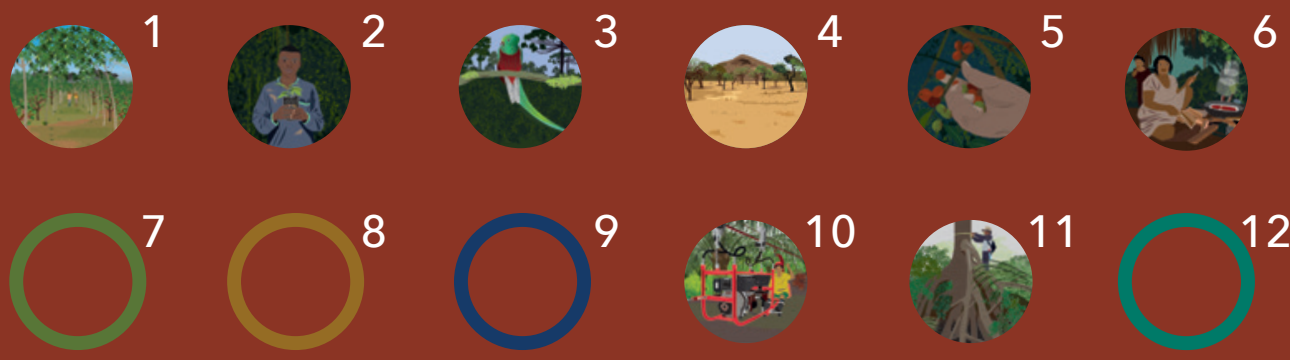

8

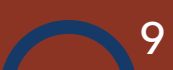

10

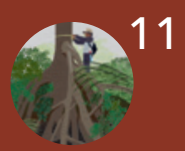

12

13

14

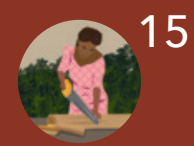

16 17

18 